\title{
CONFLICT AVOIDANCE IN SUCCESSION PLANNING
}

\author{
Eugene F. Scoles† and Max Rheinstein*
}

I

\section{INTRODUCTION}

The avoidance of problems raised by the conflict of laws is a crucial facet of the estate planner's work that can effectively be dealt with in a variety of ways. Because most estate planning results in the execution of testamentary instruments, however, this article will concentrate upon the use of the will as a conflict-avoidance device; although it will also discuss some instances in which the post-mortem operation of inter vivos transactions creates significant conflicts problems as well as some problems of intestate succession where necessary to indicate the alternatives present in a planning situation-but, since planning seldom includes an intentional intestacy, these latter instances will be limited. Moreover, since troublesome conflicts problems can arise in administration after the death of the estate owner, techniques for avoiding or alleviating these problems, too, will be treated. The article, thus, will consider conflict avoidance in succession planning in three principal divisions: execution and revocations of wills, dispositive provisions, and administration of decedents' estates.

The background of general conflicts law relating to succession, against which all planning must occur, is fairly simple to state but occasionally complicated in application. In the Anglo-American system of common law, succession to immovables is determined, in the first instance, by the law of the situs of the asset, usually the location of the land; $\mathbf{y}^{1}$ succession to movables and incorporeal assets is regulated by the law of the owner's domicile at the time of his death. ${ }^{2}$ In the absence of statute, this

† A.B. 1943, J.D. 1945, University of Iowa; LL.M. I949, Harvard University; J.S.D. 1955, Columbia University. Professor of Law, University of Illinois. Contributor to legal periodicals.

- Dr. utr. iur. 1924, University of Munich, Germany. Max Pam Professor of Comparative Law and Director of the Comparative Law Research Center, University of Chicago Law School; Member, American Law Institute. Formerly Member of Research Staff, Kaiser Wilhelm Institute of Foreign and International Private Law; Privatdozent, University of Berlin. Author, Das RechtsgeschaffT IM INTERnationalen Privatrecht (1933); Max Weber on LaW in Economy and Society (I954); Law of Decedents' Estates (2d ed. 1955). Contributor to American, German, Italian, English, and Canadian legal periodicals.

${ }^{1}$ Sec Albert V. Dicey, Conflict of Laws 535 (6th ed. 1949); Martin Wolff, Private International Law 503 (2d ed. i950); G. C. Cheshire, Private INTERnational Law 560 (4th ed. I952); Joseph H. Beale, Conflict of Laws 965 (1935); Herbert F. Goodrich, Conflict of Laws 500 (3d ed. 1949).

${ }^{2}$ See DiceY, op. cit. supra note I, at 817; WoLFF, op. cit. supra note I, at 503; Cheshire, op. cit. supra note $\mathrm{r}$, at $5 \mathrm{r} 8$; BEALE, op. cit. supra note $\mathrm{r}$, at I029; GoodrIcr, op. cit. supra note $\mathrm{r}$, at $50 \mathrm{r}$. It should be emphasized that the distinction between immovable and movable and incorporeal assets does not perfectly coincide with that between realty and personalty. It is also important to keep in mind that in the United States, the concept of domicile has lost much of its technicality and has, to a large extent, coalesced with that of residence. Cf. Rheinstein, Domicile as the Jurisdictional Basis of Divorce Decrees, 23 ConN. B. J. 280 (I949). 
general approach prevails whether the decedent died testate or intestate. ${ }^{3}$ Statutory enactments have, however, in particular instances, altered this approach by providing different or alternative results, ${ }^{4}$ and the significance of these enactments will be discussed as they arise in context.

Most civil-law countries, on the other hand, apply a single or unitary law to all assets of the deceased. This unitary approach is based on the Roman-law concept of universal succession and requires the application of the law of either the country of which the decedent was a national ${ }^{5}$ or that in which he had his domicile or residence at the time of his death. ${ }^{6}$ Several civil-law countries, however, draw a distinction between immovables and movables, applying the law of the situs to the former and the national or domiciliary law of the decedent to the latter."

The determination of the law that will be applied by the court of a given country is further complicated by the doctrine of renvoi and the varying attitudes taken towards it. If, for example, a German court has to deal with the succession to the assets left by a national of France, it looks to and follows the conflicts rules of France. Thus, to the distribution of the movables, the law of the country in which the decedent had his domicile at the time of his death would be applied; to the descent of each immovable asset, the law of the place where it is situated. Accordingly, if the French decedent had his domicile in Switzerland and left an immovable asset in Germany, the German court would apply Swiss law to the movables and German law to the immovable. However, the Swiss "law" applied would again primarily be the Swiss law of conflict of laws; but since, in the case given, Swiss conflicts law refers or, at least, seems to refer, to the law of the country of domicile, ${ }^{8}$ Swiss substantive law would be applied. These results follow because renvoi is generally accepted by the German courts. Renvoi is not accepted, however, by an Italian court. Thus, if, in the case of a French national dying with his last domicile

${ }^{3}$ See Re Dennis' Estate, 98 Vt. 424, 129 Atl. I66 (1925); DiceY, op. cit. silpra note 1, at 535, 821; Cheshire, op. cit. silpra note $\mathrm{I}$, at 519, 560; BeAle, op. cit. supta note 1 , at 969, 1034; Goodrich, op. cit. supra note $\mathrm{I}$, at $505,5 \mathrm{I2}$.

¿E.g., Wills Act, I86r, 24 \& 25 Vict. c. 114 ; Model Execurion of Wills Act, 9 U.L.A. 419 (195I). See note 14 infra.

According to the list contained in Murad Ferid and KarL Fursching, Internationales Endrycht No. 45 (1955), the countries employing this standard are: Egypt, China, Cuba, Germany, Finland, Greece, Israel, Italy, Japan, Netherlands, Poland, Portugal, Sweden, Spain, Syria, Tangier, and Czechoslovakia.

These criteria are invoked by the following countries: Denmark, Iceland, Norway, Argentina, Chilc, Ecuador, Colombia, Paraguay, Peru, Nicaragua, El Salvador, and Brazil. See ibid.

${ }^{7}$ Invoking the lex situs for immovables and the lex domicilii for movables are the following countries: France, Belgium, Luxemburg, Monaco, and Thailand. See id. No. 46 . Invoking the lex situs for immovables and the lex patriae for movables are the following countries: Bulgaria, Yugoslavia, Austria, Liechtenstein, Rumania, Turkey, and Hungary. See id. No. 47; sec also Nadelmann and von Mehren, Draft Law on Private International Law, I AM. J. Comp. L. 416, 423 (1952); WoufF, op. cit. supra note $\mathrm{I}$, at 568 . The several systems are combined in various ways in the following countrics: Switzerland, U.S.S.R., Bolivia, Uruguay, Venezuela, Costa Rica, Dominican Riepublic, Guatemala, Haiti, Honduras, Mexico, and Panama. Sce Ferid and Firschung, op. cit. supra note 5, No. 45, 48.

For an interesting appraisal of the different views and their validity in modern society, sec StATE of Israel Ministry of Justice, Succession Bill for Israel, Text and Explanatory Notes pt. 8, at 152 (unpublished Harvard Law School translation 1952).

${ }^{8}$ See Ferid and Firsching, op. cit. supra note 5, No. $45,48$. 
in Switzerland and leaving movables in Italy and an immovable asset in Germany, a decision has to be made by an Italian court, it simply applies the substantive law of France. 9 If, in a given case, therefore, the circumstances present the possibility that litigation may at some future time arise in the courts of one or more foreign countries, the draftsman ought to obtain information not only as to the general choice-of-law rules of each of these countries, but also as to the attitude taken in each with respect to the problem of renvoi.

With this variation in the choice-of-law rules of different jurisdictions and with the variations that occur in the internal laws on wills, descent, and distribution, it is apparent that many potential conflicts problems must be considered in the careful handling of the succession affairs of a client.

II

Execution and Revocation of Wills

A. Execution

\section{x. Capacity of the Testator}

The starting point in complying with the requisite formalities of will-execution is the testamentary capacity of the estate owner. In this connection, it is important to distinguish between problems of personal capacity or competence and other limitations upon the freedom of testation, which will be discussed subsequently. Capacity is determined, in absence of statute, by the law governing the succession of the assets subject to the will. ${ }^{10}$ To avoid the possibly invalidating effect of incapacity, therefore, the testator should be capable under each of the following laws: the law of his domicile, the law of his nationality, the law of the situs of his immovables, and, in some instances, the law of the situs of his movables. Since personal law is subject to change, any anticipated changes of residence or of nationality (or of allegiance, in case of service in foreign armed forces) should be considered to assure future capacity under such possibly applicable law.

In civil-law countries, it should be noted, several distinctions are made which are not generally observed in this country. The capacity to transact legal business of any kind is treated as an incident of an individual's general status. This general capacity may be lacking because the individual is an infant or because he has been judicially deprived of the capacity to transact business on account of mental disease, feeblemindedness, habitual drunkenness, or being a spendthrift. The careful draftsman should, therefore, investigate these possibilities in any case in which there arises a suspicion that such a judicial declaration may have been made in the country of nationality, domicile, or situs of assets. It should also be noted that an individual, though competent to transact legal business in general, may yet be incompetent to make a will, or vice versa. ${ }^{11}$

${ }^{\circ}$ See Italian Civir Code art. 23, 30 (1942).

${ }^{10}$ See WolfF, op. cit. supra note $\mathrm{I}$, at $58 \mathrm{I}$.

${ }^{11}$ See, e.g., German Civil Code art. 2229, 2238 para. 3, 2247 para. 4 (r924) (although an individual below the age of twenty-one is not generally competent to transact legal business, he may execute 


\section{Formalities}

The formalities of execution of a testamentary instrument constitute one of the most important technical hurdles a lawyer has to overcome. Yet, if he is aware of the possibilities and has available the needed fact information, a satisfactory solution can generally be obtained.

Under the common-law rule governing the execution of an instrument which is to dispose of immovables, the testator must have complied with the formalities of the law of the situs; ${ }^{12}$ in order validly to dispose of movables, the testator must have complied with the formalities of the law of his domicile as of the time of his death. ${ }^{13}$ The exclusive application of common-law rule governing the disposition of movables is impracticable, however, because at the time of the execution of the instrument, a testator cannot know where he will reside at the uncertain moment of his death. Fortunately, therefore, the common law has been modified in most states by statutes which provide, in varying language and with varying details, that a testamentary instrument is to constitute a valid disposition of movables if the formalities of execution required by the law of any one of the following have been observed: ${ }^{14}$

a. the jurisdiction in which the instrument was executed;

b. the jurisdiction in which the testator was domiciled at the time the instrument was executed;

c. the jurisdiction in which the testator was domiciled at the time of his death; or

d. the jurisdiction in which the assets in question are situated.

These statutes do not always effect what they seem to promise, however, especially where immovables are involved. ${ }^{15}$ Whenever a testator owns immovables in a com-

a will; but he must use a special kind of notarial will-he cannot make an unwitncssed holographic will); French Crvil CODE art. 904 (54th $\mathrm{cd}$., Dalloz 1955) (an individual between the ages of 16 and 2 cannot by will dispose of more than one half of that part of his estate of which a person can dispose in general).

1s Restatement, Conflict of Laws $\$ 249$ (1934). See also note I stipra.

${ }^{13}$ Moultrie y. Hunt, 23 N.Y. 394 (I86r). See also note 2 stipra.

${ }^{14}$ For a classification of these laws as well as an analysis of their operational variations, see Rabel, The Form of Wills, 6 VAND. L. Rev. 533 (1953); Lorenzen, The Validity of Wills, Deeds, and Contracts as Regards Form in the Confict of Laws, 20 YALE L. J. 427 (I9II). The following are illustrative of the statutes adopted by most of the states of the United States: ARIz. Code ANN. $\$ 38-215$ (I939); Ank. Stat. Ann. \$6045 (Supp. I955); Cal. Prob. Code $\$ 362$ (Supp. I953); Conn. Gen. Stat. §6951 (1949); GA. CODE \$I13-709 (I933); IdAHo Code ANN. \$15-222 (1949); Ill. Rev. Stat. c. 3, \$85 (I953); lowa Code $\$ 633.49$ (1954); Kan. Gen. Stat. \$259-609 (I949); LA. Rev. Stat. ANn. \$ 9:2401 (1950); Me. Rev. Stat. c. I54, \$I4 (I954); Md. Ann. Code Gen. Laws art. 93, \$365 (I95I); Mass. AnN. Laws c. I9I, \$5 (I955); Mich. Stat. ANN. \$27.3178(97) (Supp. 1955); MinN. STAT. \$525.183 (I953); Mont. Rev. Codes ANn. $\$ 91-115$ (1947); Neb. Rev. Stat. \$30-204 (I943); Nev. Comp. Laws \$9929 (1929); N. H. Rev. Stat. ANN. \$55I:5 (1955); N. M. Stat. Ann. \$30-T-10 (1953); N.Y. Dec. Est. Law $\$ \S 22 a, 23 ;$ N. D. Rev. Code $\$ 56-0306$ (1943); OkLA. STAT. tit. 84, \$72 (I95I); R. I. GeN. LAwS c. 566, $\$ 35$ (1938); S. C. CODE $\$ 19.207$ (1952); S. D. CODE $\$ 56.0212$ (1939);

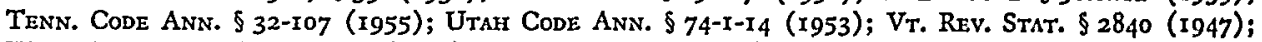
Wash. Rev. Code $\$$ II.12.020 (I95I); WIS. Stat. $\$ 238.07$ (1953); Wro. CoMp. Stat. ANn. \$6-503 (1945). See also Cohn, Der Richtung und Wiederruf von Testamenten mit Englischen Beziehungen in der Schweiz, 1952 SchweIzERISCHE JURISTENZERTUNG I29.

${ }^{15}$ See, e.g., Sternberg v. St. Louis Union Trust Co:, 394 Ill. 452, 68 N.E.2d 452 (I946). 
mon-law jurisdiction, therefore, the formalities prescribed by the law or laws of the situs of each immovable asset should rigorously be observed.

The safest course for the draftsman to follow is to have the instrument so executed that there are cumulatively observed the formalities prescribed in all common-law jurisdictions. Compliance with the prescription is not difficult. The common-law knows two forms of wills, the witnessed will, available in all jurisdictions, and the unwitnessed holographic will, available only in some. ${ }^{16}$ The latter should, consequently, be avoided whenever a testator is likely to leave assets in more than one jurisdiction, and the following formalities for a witnessed will, which are essentially the same in all common-law jursdictions, although the statutes vary in detail, should be observed in the execution of every testamentary instrument:

I. The will should be declared in an instrument in writing.

2. The instrument should be signed by the testator or, if he cannot do so, by another person who subscribes upon his request and in his presence.

3. The signature of the testator or of the person subscribing upon his request and in his presence should be placed immediately following the text of the instrument, without any blank space preceding it, and in no other place.

4. There should be at least three attesting witnesses. ${ }^{17}$

5. None of the attesting witnesses should be:

a. a beneficiary under the instrument or be appointed in it as executor or trustee;

b. a spouse of a beneficiary under the instrument or of a person appointed in it as executor or trustee;

c. a business partner of a beneficiary under the instrument or of a person appointed in it as executor or trustee;

d. an officer or a stockholder in a corporation named in the instrument as a beneficiary or appointed in it as executor or trustee; or

e. a resident of a city, town, county, or state to which there is made in the instrument a gift tending to alleviate its tax burden-such as a gift for the benefit of the poor of the town.

6. The attesting witnesses should be expressly asked by the testator to attest "the execution of his will."

7. In the case of a testator who is able to write his signature, all the witnesses should either:

${ }^{10}$ Louisiana recently adopted a new statutory will form in addition to the codal wills previously available. LA. Rev. Stat. AnN. \$9: 2442-44 (Supp. 1955); see Comment, The New Loutisiana Wills Act, 28 Tul. L. Rev. 288 (I954).

${ }^{17}$ The conflict-of-laws significance of the requirement by seven states that there be three witnesses to a will has been reduced by the enactment in these states of statutes recognizing wills valid under the law of the place of execution. Conn. Gen. Stat. \$695I (1949); GA. Code § II3-709 (I933); ME. Rev. Stat. c. I54, \$I4 (I954); Mass. ANn. Laws c. 191, \$5 (I955); N. H. Rev. StAT. AnN. \$551:5 (I955); S. C. CoDE $\$$ I9.207 (I952); VT. REv. STAT. $\$ 2840$ (I947). The conflict-of-laws effects of the requirements of the Louisiana Code are also alleviated by a similar provision. La. Rev. Stat. Ann. $\S 9: 2401$ (1950). 
a. observe the signing of the instrument by the testator; or

b. hear him expressly state that he acknowledges as made by him a signature which is already upon the instrument and which is pointed out to, and actually seen by, all the witnesses.

In the case of a testator who is not able to write his signature, all the witnesses should observe that:

a. an express request to sign the instrument is directed by the testator to the person by whom the instrument is to be signed; and

b. the instrument is signed by the person so requested and that such signing is done in the presence of the testator.

8. The witnesses should be told that the instrument is to be the testator's will.

9. Every witness should affix his signature and address to the instrument in the presence of the testator-i.e., within his unobstructed line of vision.

I0. All witnesses, the testator, and, if necessary, the person signing for him should be present simultaneously during the entire transaction of execution.

II. The instrument should be dated by fully and correctly stating the place and the day, month, and year of its execution.

12. The observation of all the formalities listed, except those stated under 3 and 5, above, should expressly be recited in the attestation clause, which should also indicate the number of pages of which the instrument consists.

13. Every sheet of the instrument should be initialed by the testator and all the witnesses; the sheets should be numbered consecutively, and be securely fastened together.

In the civil-law countries, the rule of locus regit actum is universally observed. ${ }^{18}$ For the disposition of assets situated in a civil-law country, therefore, observation of the formalities of the law of the place of execution is sufficient in all cases, unless the testator is a national of the Netherlands or the Republic of Indonesia, in which case the will ought to be executed before the Dutch or Indonesian consul, as the case may be. ${ }^{19}$ Execution before the consul of the country of the situs is also advisable in all cases in which the instrument is to dispose of immovables, a ship, or an aircraft, because difficulties may otherwise be encountered when the testamentary transfer is sought to be recorded upon the local record of titles or to be registered in the local registry of deeds.

\section{B. Revocation}

The discussion of problems of execution must inevitably touch on the troublesome matter of revocation, for perhaps "revocation is merely the converse of execution ... whether an instrument is a will is determined not only by the manner of its

\footnotetext{
${ }^{18}$ See Max Rheinstein, Das Rechtsgeschaeft im Internationalen Privatrechr 4 (i933); Franz Schlegelberger, Recht'svergleichendes Handwoerterbuch 359 (1933). Sce also Gonzalo E. Parra, A. Die Regel "locus regit actum" und die Formen de Testamente-La regl "locus regit ACTUM:" Y FORMA DE LOS TESTAMENTOS 306 (i955) (text in German and Spanish).

${ }^{10}$ See Netherlands Civil Code art. 992 (1829).
} 
execution but also by the manner of its attempted revocation." 20 Revocation by intentional act, such as cancellation, obliteration, or destruction, is generally governed under Anglo-American law by the law of the last domicile in the case of movables ${ }^{21}$ and by the law of the situs in the instance of immovables. ${ }^{22}$ If there is a statute in the forum or the state of the governing law, such as Lord Kingsdown's Act ${ }^{23}$ or the Uniform Wills Act, ${ }^{24}$ however, the answer is uncertain; for, these acts purport to refer questions of valid execution to the law of states other than the forum, and the issue then becomes one of whether problems of "revocation" are to be treated as problems of "execution."25 The matter is further complicated by the alternative references of the statutes in an attempt to validate-i.e., to carry out the testator's intention. In so far as an intentional revocation is meant to have effect in a civil-law country, however, the rule of locus regit actum applies, which means that the revocation is effective in every civil-law country if the formalities of the law of the place of acting have been observed. ${ }^{26}$

Difficult problems of choice of law can also arise in connection with the possible revocation of a will by operation of law. At common law, the will of a man was revoked when, subsequent to its execution, he married and a child was born to him; the will of a woman was revoked by her subsequent marriage. Modern statutes in this country and other common-law jurisdictions have considerably modified these rules, frequently substituting for the total inoperativeness of the instrument the provision of a share in the estate for the spouse or for a child born after the execution of the instrument. ${ }^{27}$ The conflicts problems raised by such statutes will be discussed below in connection with the problems caused by laws giving certain persons rights to share in a decedent's estate in contradiction to, or in supplementation of, the provisions of a will. ${ }^{28}$ A more modern development in revocation by operation of law is found in a few states of the United States, where a testamentary provision in favor of the testator's spouse becomes ineffective in the case of divorce. ${ }^{29}$

${ }^{20}$ Re Barries' Estate, 240 Iowa 43r, 447, 35 N.W.2d 658, 666 (1949) (Smith, J., dissenting).

${ }^{21}$ See Rabbe v. McAllister, I77 Md. 97, 8 A.2d 922, (r939); Cottrell v. Cottrell, L.R. 2 P. \& D. 397 ( 1872 ).

${ }_{22}$ See Re Barrie's Estate, 240 Iowa 43I, 35 N.W.2d 658 (1949); In re Kimberly's Estate, 32 S.D. I, I4I N.W. 1081 (1913); WoLFF, op. cit. supra note $\mathrm{I}$, at 594 .

${ }_{23}$ Wills Act, $186 \mathrm{r}, 24$ and 25 VICT. c. II4. Canadian variations of this act have been adopted by Saskatchewan (I931) and Manitoba (1936). See John D. Falconbridge, Conflict of Laws 546 (2d ed. 1954). Similar statutes are also in effect in Alberta, British Columbia, Nova Scotia, Ontario, and Quebec. See Cohn, supra note I4.

${ }^{21}$ For a more detailed examination of the extent to which this act and others of similar purpose have been adopted, sec note 14 stlpra.

${ }^{25}$ See Re Barrie's Estate, 240 Iowa 431, 35 N.W.2d 658 (1949); In re Traversi's Estate, I89 Misc. 251,64 N.Y.S. 2d 453 (Surr. Ct. 1946). Three states expressly include both execution and revocation in their statutes. See Mont. Rev. Codes ANn. $\$ 9$ I-II5 (I947); OkIa. Stat. tit. 84, 72 (I95I); S. D. CODE $§ 56.0212$ (1939).

"See Rheinstein, op. cit. supra, note I8.

${ }^{27}$ See Max Rheinstein, Law of Decedents' Estates 284 (2d ed. 1955); Graunke and Beuscher, The Doctrine of Implied Revocation of Wills by Reason of Change in Domestic Relations of the Testator, 5 WIs. L. REv. $3^{85}$ (1930).

${ }^{28}$ See text at note 46 et seq. infra.

${ }^{20}$ See, c.g., Ala. COde tit. 6r, $\$ 15$ (Supp. I953); ARK. Stat. ANN. \$60-407 (Supp. I955); FlA. Stat. $\$ 732.261$ (1953); GA. CODE $\S$ Ir3-408 (I933). 
Such statutes usually contain no exception for contrary testamentary directions. In the civil-law countries, it may be observed, revocation by operation of law does not appear presently to play an important role, except in the case of divorce.

The problem of ascertaining the law by which it will be determined whether or not a will, or a provision in it, has been revoked by operation of law, is unsettled. $^{30}$ For the draftsman, it is practically impossible to foretell the disturbing effects which events occurring subsequent to the execution of a client's will may have on the effectiveness of the instrument. Consequently, he should impress the client with the necessity of having his will reviewed and, if necessary, revised in the case of his marriage, divorce, or removal from one jurisdiction to another. Periodic review is desirable for other reasons, too, especially to guard against the effects of changes which may have occurred in any one of the laws which are, or may become, relevant with respect to the ultimate effectiveness of the client's testamentary scheme.

The many possibilities of invalidity that may operate upon a testamentary instrument also suggest that the cautious draftsman will advise his client of alternatives in every case and suggest means of holding assets and their location during his lifetime so that intestacy will approximate the testator's intention as nearly as possible. In short, a planned intestacy is the final insurance against failure of the testamentary scheme and should be considered if the opportunity is available.

\section{III}

\section{Dispositive Provisions}

\section{A. Limitations on Freedom of Testation}

\section{Protecting the Family}

In most countries, an individual's freedom to transfer his assets at death is hedged about by limitations of which the draftsman must be aware. As these limitations vary from jurisdiction to jurisdiction, they present many conflict-of-laws complications. In western civilization, the principal limitations upon testation grew out of policies favoring the protection of the family. ${ }^{31}$ This protection may be given in several ways. At common law, the person sought to be protected-i.e., the spouse-was given a property interest in every piece of realty of which the other spouse was seised of an estate of inheritance at any time during coverture.

${ }^{30}$ Most American states follow the general rules of succession, ste, e.g., Lee v. Monks, 318 Mass. 513, 62 N.E.2d 657 (1945); Re Wehr's Will, 247 Wis. 98, 18 N.W.2d 709 (1945); Barnes v. Graves, 259 Ky. 180, 82 S.W.2d 297 (1935); Re Dennis' Estate, 98 Vt. 424, I29 Atl. 166 (1925); but the effect of the statutes is not entirely clear. Some states, on the other hand, indicate that some law other than that usually governing succession may be applied. See, e.g., In re Traversi's Estatc, 189 Misc. 251, 64 N.Y.S.2d 453 (1946); cf. Gailey v. Brown, 169 Wis. 444, 171 N.W. 945 (1919). For express statutory references, see statutes cited note 25 supra. England appears to apply the law of the matrimonial domicile in case of revocation by subsequent marriage. See In re Martin, [1900] P. 21 I, 240; sce also Re Goods of Reid, L.R. I P. \& D. 74 (1866); Seifert ข. Seifert, 32 Ont. L.R. 433 (1914), 23 D.L.R. 440 (1915).

${ }^{31}$ See Nussbaum, Liberty of Testation, 23 A.B.A.J. 183 (1937); Dainow, Forced Heirship in French Law, 2 LA. L. Rev. 669 (1940); McMurray, Liberty of Testation and Some Afodern Limitations Thereon, I4 ILI. L. REv. 96 (1919). 
As this interest arose during the lifetime of the owner of the asset of realty in question, it could be affected neither by his disposition inter vivos nor by his will. This technique of protecting the spouse of an owner of realty by means of dower, curtesy, or homestead, as the case may be, is still used in numerous states of this country, and it seems not to have disappeared completely in the other countries of the common law.

Another way of protecting certain members of the decedent's family against disinheritance is that of granting them the right to take a certain minimum share in the estate, even against the wishes of the testator. In the French Civil Code and those numerous laws following its pattern, the end is achieved by limiting the portion of the estate of which an owner may dispose by will. An indefeasible share in the estate appertains to each child or to each of certain other classes of relatives, such as brothers and sisters, parents, grandparents, or even parents-in-law. Thus, if a property owner dies being survived by one legitimate child, he may, under the French Civil Code, dispose by his will of no more than one-half of his estate; if he dies being survived by two legitimate children, of no more than one-third; and if he dies survived by three or more legitimate children, of no more than onefourth. $^{32}$ If there are three children, each is, thus, entitled to a one-fourth share in each asset of the estate as a tenant in common together with the other children and the legatee or legatees in whose favor the testator has made provision in his will. If that provision was for more than one-fourth, it is reduced to that portion.

Under the German Civil Code and those other laws which follow its pattern, a substantially equivalent result is achieved by a slightly different technique. Each member of the favored class is given a claim to the payment of an amount of money corresponding to the value of a certain portion of the estate. ${ }^{33}$ If a testator who dies being survived by his wife and two children has by his will given all his estate to a stranger, the latter takes as "heir," but has to pay to the widow the money value of one-eighth and to each of the children the money value of three-sixteenths of the net estate. ${ }^{34}$

In the United States, an "indefeasible share" of the surviving spouse has been established in almost all states as to personalty and, in a great many, as to realty as well, either as a substitute for common-law dower or curtesy, or as an alternative to be elected by the surviving spouse in lieu of dower or curtesy. ${ }^{35}$ This indefeasible share under the American statutes is similar in structure to the forced portion of the civil law, except in one respect. In this country, the indefeasible share is a portion in the net estate as it exists at the time of the owner's death and usually after the payment of taxes, debts, and expenses. If the owner has, therefore, before his death, given away all his property by gifts inter vivos, the interest of the surviving spouse

${ }^{32}$ French Crvil Code art. 913 (54th ed., Dalloz r955).

${ }^{33}$ German Civil Code art. 2303 et seq (1924).

36 Id. at art. 2303.

${ }^{38}$ E.g., FLA. StAT. $\$ 73$ r.34 (1953); Iowa Code $\$ 636.5$ (1954); MrNw. Stat. $\$ 525.16$ (r953); N. Y. Dec. Est. Law $\$ 18$; see also 3 Chester Garfield Vernier, American Family Laws $\$$ i 89 (1935). 
may be defeated. Protection against such defeasance of the indefeasible share by gifts inter vivos is of limited value in most of our states. ${ }^{36}$ In the civil-law countries, however, gifts made either in a general or in a certain way, or within a certain period before the donor's death are ineffective as against those persons who are entitled to a forced share in his future decedent estate. ${ }^{37}$ Provisions which thus limit a property owner's freedom to dispose of his assets not only by will, but also by gift inter vivos, must be kept in the mind of the attorney who develops an estate plan for a client owning assets in a civil-law country.

In England, the system of the forced share, which had been established there under the influence of the Church, disappeared in the late seventeenth and early eighteenth centuries. This was followed by the system of dower and curtesy. Restricted by statutes in 1833 , dower and curtesy were abolished in 1925, and a property owner's freedom of testation was complete. ${ }^{38}$ A new system of indefeasible protection of family dependents has now come to obtain, however, in numerous jurisdictions of the British Commonwealth, including England. Following a pattern set by a New Zealand law of rgoo, a family member who was dependent upon the decedent may, by judicial discretion, be granted the right to a maintenance provision out of the assets of the estate. ${ }^{39}$

Nearly everywhere, as well, temporary protection is given certain dependents, especially the surviving spouse and minor children, by the right to receive out of the estate a certain amount for their support and maintenance for a short period following their provider's death. Such claims for an allowance for the surviving spouse or minor children, although recognized in many parts of the world under both the common and civil law, vary greatly in detail..$^{40}$

Family protection is, finally, achieved in several jurisdictions of this country ${ }^{41}$ and in numerous civil-law countries through the operation of the various systems of community property, whose effect in the case of a married couple is that certain assets belong to neither the husband nor the wife, but to both; so that at the death of one spouse, only one-half of the community fund belongs to his decedent estate, while the other half belongs to the surviving spouse. Under the approach prevailing in the United States, most problems of which assets, if any, are community property, as between the spouses at least, is determined by the law of the jurisdiction in which

${ }^{36}$ Cf. Newman v. Dore, 275 N.Y. 37x, 9 N.E.2d 966 (1937); Norris v. Barbour, 188 Va. 723, 51 S.E.2d 334 (1949); PA. STAT. tit. 20, §5301.II(19) (1936).

${ }^{37}$ See RrIeINSTEIN, op. cit. supra note 27 , at 63 .

38 \& 4 Will. 4, c. 105 (1833); I5 Geo. 5, c. $23, \$ 45$ (I) (1925).

${ }^{30}$ E.g., Family Provision Act, I \& 2 Geo. 6, c. 45 (I938); 64 Vicr. No. 20 (New Zealand 1900), as amended, II Geo. 6, No. 60, §15 (New Zealand 1947); 6 EDw. 7, No. 2074 (Victoria I906); 3 Geo. 5, No. 7 (Tasmania I912); 5 Geo. 5, No. 26 (Queensland 1914); 11 Geo. 6, c. 12 (Alberta I947), as amended, 15 Geo. 6, c. 91, 33 (Alberta 195I); B. C. Rev. Stat. c. 336 (I948); 4 Man. Rev. Stat. c. 264 (1954); ONt. Rev. Stat. c. Ior (1950); I Sask. Rev. Stat. c. 121 (1953). Sce also Laufer, Flexible Restraints on Testamentary Freedom-A Report on Decedents' Family Maintenance Legislation, 69 HaRv. L. Rev. 277 (1955).

10 Administrative problems concerning allowances are discussed at note 162 infra. Rico.

${ }^{11}$ E.g., California, Idaho, Nevada, New Mexico, Washington, Arizona, Texas, Louisiana, and Pucrto 
the married couple was domiciled at the time of the acquisition of the asset in question. ${ }^{42}$ This is because most situs courts would refer the question to the domicile of the parties. Also, it must be kept in mind that under the substitution rule, which is generally applied in this country, the proceeds acquired from the sale or other alienation of an asset retain the character of the asset alienated. While the substitution rule and the situs reference determine most cases, exceptions are still sufficiently numerous to warrant investigation of both the law of the situs of assets and the personal law of the parties since their marriage for law that may have application to their marital property. ${ }^{43}$

With respect to the property interests of one spouse in the realty of the other (e.g., dower, curtesy, homestead), the conflicts rule is simple: they are determined for each parcel of land by the law of its situs. ${ }^{44}$ Not so clear, however, is the conflicts rule which indicates that legal system by which it is determined whether or not a benefit given by the will of one spouse to the other is in lieu of dower or in addition thereto. ${ }^{45}$ The draftsman should, therefore, in every case, first clearly spell out whether the provision is intended to have one of these effects or the other; and, if the provision is meant to be in lieu of dower or other interest, he ought to ascertain whether this effect can be achieved under the laws of both the situs of the land and that jurisdiction of which the testator is likely to be a domiciliary at the time of his death.

The extent to which a testator's freedom of testation is limited by these family protection doctrines is determined by the law that governs descent and distribution of the estate. With respect to movable property located in a common-law jurisdiction, the court of the situs can be expected to apply the law of the state of the testator's last domicile, ${ }^{46}$ or to allow the assets to be collected by the domiciliary administrator, or to forward them to the domicile for distribution. Immovable property, on the other hand, must be expected to be treated by the law of the situs in accordance with its own internal rules. ${ }^{47}$

${ }^{4}$ See I Ernst Rabel, Conflict of Laws c. Io (I945); Harold Marsh, Marital Property in ConFuICT of LAws (1952); Goodrich and Coleman, Pennsylvania Marital Communities and Common Law Neighbors, 96 U. PA. L. Rev. I (1947); Neuner, Marital Property and the Conflict of Laws, 5 LA. I. Rev. I67 (1943); Leflar; Community Property and the Confict of Laus, 2 I Calif. L. R'Ev. 221 (1933); Stumberg, Marital Property and Confict of Laws, II TEx. L. Rev. 53 (1932); Harding, Matrimonial Domicile and Marital Rights in Movables, 30 Mrch. L. Rev. 859 (1932); Goodrich, Matrimonial Domicile, 27 YaLe L. J. 49 (1917).

${ }^{13}$ Cf. I RABEL, op. cit. supra note 42, at 337-43; MARsh, op. cit. supra note 42, at 100-03.

1" E.g., In te Estate of Randolph, I75 Kan. 685, 266 P.2d 315 (1954); Spence v. Spence 239 Ala. -480 , I95 So. 717 (1940); Ehler v. Ehler, 214 Iowa 789,243 N.W. 59I (I932); Bullen v. Wisconsin, 240 U.S. 625 (1916).

45 $C$. text and citations at note 174 infra.

${ }^{10}$ See note 44 stupra. An exception is constituted by Mississippi, where a unique statute provides for the application of its own law to the succession to all assets, both immovable and movable, which are "situated in Mississippi. Miss. Code Ans. $\$ 467$ (1942).

${ }^{47}$ But cf. Estate of Clemmons, 242 Iowa 1248, 49 N.W.2d 883 (195I); Proctor v. Frost, 89 N.H. 304, I97 Atl. 813 (1938); Hite v. Hite, 30r Mass. 294, I7 N.E.2d I76 (1938); Polson v. Stewart, 167 Mass. 211 , 45 N.E. 737 (I897); In re Peabody's Estate, II5 N.Y.S.2d 337 (Sup. Ct. 1952); In re Ruperti's Estate, 194 Misc. 376 , 86 N.Y.S.2d 887 (Surr. Ct. 1949); In re Bernie's Estate, 74 N.Y.S.2d .887 (Surr. Ct. 1947). 
If movable or immovable assets are located in a civil-law country, the draftsman has to determine what choice-of-law rules the courts at the situs will apply. Thus, if a national of the United States owns immovables in France, the extent of his power to dispose of them would be determined by the rules of French law concerning the disposable portion. ${ }^{48}$ As to movables situated in France, however, the law applied by the French courts would be that of the testator's place of residence as of the time of his death. ${ }^{49}$ If, at that time, he was a resident of France, the French courts would apply French substantive law; if he was a resident of a jurisdiction following the last domicile reference, the French courts would apply the internal law of that jurisdiction; but if, at the time of his death, the decedent was a resident of Italy, then the French would look to Italian conflicts law ${ }^{50}$ and would, by that law, be referred to the law of the country of which the decedent was a national at the time of his death, ${ }^{51}$ which, in our hypothetical, would be the law of the United States. Unfortunately, however, the United States does not have one law on the distribution of decedents' estates, and so it is uncertain to which law the Italian conflicts rule would refer, although it would likely be that the internal law of the American jurisdiction in which the testator resided at the time of his death would be applied. ${ }^{62}$

A different approach would be followed, however, if at the time of his death the American owner of French movable assets resided in Germany, a country which, in contrast to Italy, readily accepts renvoi. In such a case, the French court, being by its own law referred to the conflicts law of Germany, would apply that law to which German conflicts law refers-i.e., the law of the country of which the decedent was a national. In contrast to an Italian court, a German court would not, however, immediately search for the American substantive law, but for the American rule of conflicts law. Before the era of Erie R. R. v. Tompkins, ${ }^{53}$ the German courts assumed that there existed a uniform conflicts law for the United States and that that rule referred problems relating to a decedent's movables to the law of the decedent's domicile at death. Since, in our hypothetical, that domicile was in Germany, German substantive law would be applied. And although the notion of a uniform federal law of conflicts no longer exists, ${ }^{54}$ the states so uniformly apply the domicile rule that it can still be expected to be applied by the courts of Germany and other countries applying the rule of the national law..$^{55}$

If the national of the United States who dies leaving movable assets in France had his residence in. England at the time of his death, the case may be further

¿s See Henri Batiffol, Traité de droit international privé 702 (2d ed. 1955).

1 Ibid.

${ }^{80}$ See $i d$. at 352 .

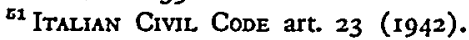

${ }^{62}$ Cf. Rheinstein, Lo statuto personale dei sudditi degli Stati Uniti d'America I GiurisprudenzA COMPARATA DI DIRITTO INTERNAZIONALE PRIVATO I4I (1937).

${ }^{53} 304$ U.S. 64 (1938).

It See Klaxon v. Stentor, 313 U.S. 487 (I941); Griffin v. MeCoach, 313 U.S. 498 (1941).

${ }^{5}$ Cf. Rheinstein, Das Kollisionsrecht im System des Verfassungstechts der Vereinigten Stanten von Amerika, i Festschrift fuer Ernst Rabel 539 (1954); Leo Rape, Internationales Privathecht 145 (4th ed. 1955). 
complicated by the possibility that the decedent's domicile, as defined by English notions, does not coincide with his residence, as defined by French law. In such a case, it is possible that under French notions, the decedent was a resident of England, and under English notions, a domiciliary of France. The French court would then be referred to the English conflicts law, which, in turn, would refer the case back to French law. Since English courts practice not only the simple, but also the double renvoi, they might well regard the new reference to the law of France as one to French conflicts law and accept that law's reference to the law of England. ${ }^{\text {.6 }}$ The French courts would probably assume that the English courts would stop at this point and decide the case under English substantive law. That the French courts would exercise, however, the power of an English court under the English Family Maintenance Act to burden the estate with the payment of annuities to dependent relatives may well be doubted.

These various hypothetical cases are presented to indicate to the draftsman how difficult, or even hopeless, it may be in some cases for him to foresee whether or not his client's testamentary scheme will stand up against attacks by persons claiming under the forced heirship or family maintenance laws of some foreign country. The only safe way to avoid such contingencies, therefore, is to see that at the time of the death, the client will not own assets within a country whose courts are likely to give effect to its own forced heirship laws or those of some other country to which they may be referred by their conflicts rules.

The end of protecting a testator's family against disinheritance has been pursued not only by statutes giving indefeasible rights to the persons sought to be protected, but also, indirectly, by statutes limiting the validity of gifts to such persons as an illegitimate child, ${ }^{57}$ or a mistress, ${ }^{58}$ or to those in a position to exercise undue influence over the testator's mind. ${ }^{59}$ Of particular importance in this respect are those statutes which limit a testator's freedom to make testamentary gifts to charities. These statutes are of two types. Statutes of the first type interdict gifts to charities in testamentary instruments executed within a short time prior to death. ${ }^{60}$ These "hell-fire statutes" were designed to vitiate deathbed "soul-saving" gifts by presuming a kind of incompetence or undue influence by reason of the fear of the hereafter. ${ }^{61}$ The second type of statutes is that which prohibits the gift of more

${ }^{20}$ Cf. In re Annesley [1926] Ch. 692.

${ }^{67}$ E.g., S. C. Code $\S$ I9.238 (1952); French Civil CODE art. 908 (54th ed., Dalloz I955).

${ }^{\mathrm{5} 8}$ E.g., S. C. CoDE $\$ 19.238$ (1952).

${ }^{50}$ E.g., under the laws of France, as well as those of Louisiana and numerous other jurisdictions following the French pattern, a legacy cannot be given to the testator's guardian, French Crvil Code art. 907 (54th ed., Dalloz 1955), the physician by whom he was treated or the spiritual adviser by whom he was assisted in his last illness, id. art. 909 , or any officer of the ship on which the testator was a passenger when he made his will. Id. art. 995.

${ }^{00}$ E.g., Fla. Stat. $\$ 73$ 1.19 (1953); Ohro Rev. Code $\$ 2107.06$ (1953); Pa. Stat. Ann. tit. 10, 1 17, (Supp. 1955); id. at tit. 20, $\$$ 180.7 (r950); D. C. Cone ANN. $\$ 19-202$ (1951).

${ }^{02}$ The effective operation of these provisions can perhaps be limited by adding new charitable gifts to the estate plan by way of codicil, so as to avoid having the entire will re-executed. Appropriate protective wording of the codicil may be helpful to avoid any possible invalidation of the total will through a concept of republication by codicil. Cf. PA. Stat. ANn. tit. 20, \$ I80.7 (I) (1950). 
than a certain portion of the estate when designated members of the family survive the testator. ${ }^{62}$ Often called "charity-begins-at-home statutes," these are designed to assure provision for those for whom the state feels the testator should have concern. These two types of statutes may be combined in various ways to give effect to these policies, both of which have root in the concern for the family and its reasonable expectation not to be deprived of the "family fortune." ${ }^{33}$

Consistent application of the policy of family protection would require that in the case of a testator leaving assets in several jurisdictions, there ought to be applied the limiting laws of that jurisdiction, and only that, which is legitimately concerned with the protection of the testator's family-i.e., that of his domicile or nationality, depending upon which of these contacts is regarded as the relevant one at the forum. ${ }^{64}$ Several American states have, nevertheless, applied their own laws when dealing with immovables situated within their territories. ${ }^{65}$ In computing the disposable share, they have either taken the estate as a whole-i.e., including the assets situated outside of the forum state ${ }^{66}$-or only the assets situated within it. ${ }^{07}$ Under a third method, the court considers not only the value of the assets situated outside of the forum state, but also the value of the benefits which the heir or other person protected has received in other jurisdictions. ${ }^{68}$

Statutes designed to protect the families of testators against disinheritance must be distinguished from statutes intended to prevent the accumulation of wealth in the "dead hand"-i.e., in the hands of the church, charities, and other corporations and institutions. Such mortmain acts exist in several of the states of the United States and in some foreign countries. The authority of a corporation to receive or hold property may be limited by a prohibition against bequests or devises to it or by a maximum amount of property, particularly realty, that it can hold. ${ }^{60}$ Violations

e2 E.g., Iowa Code $\$ 633.3$ (1954); N.Y. DEc. EsT. LAw $\$$ I7.

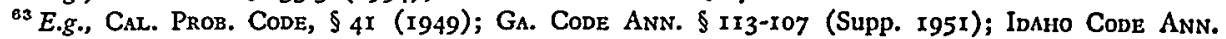
$\S 14-326$ (1948); Miss. Code ANN. $\$ 671$ (1942); Mont. Rev. Codes ANN. $\$ 91-142$ (1947).

"4f Cf. Wilson, Computation of the Legitime When Estate of the Deceased Consists of Assets in Several States, to LA. L. Rev. 525 (1950); Scoles, Conflict of Laws and Nonbarrable Interests in Administration of Decedents Estates, 8 U. FLA. L. Rev. I5I, I68 (1955). On the problem of the law determining the validity of gifts to beneficiaries of a certain kind, see also WoLF, op. cit. supra note $\mathrm{r}$, at 577; Cheshire, op. cit. supra note $\mathrm{r}$, at 522; Dicey, op. cit. supra note $\mathrm{I}$, at 820; Breslaucr, Conflict of Laws in Restrictions of Freedom of Testation, 27 Iowa L. REv. 425 (1942). For complications as to gifts to aliens, see text at note 107 infra.

${ }^{65}$ See Joslin, Conflict of Laws Problems Raised by "Modern Mortmain Acts," 60 Dick. L. Rev. 7 (1955); Joslin, "Mortmain" in Canada and the United States, 29 Can. B. Rev. 621 (1951).

${ }^{8 B}$ See Estate of Lewis, 32 La. Ann. 385 ( 1880 ).

${ }^{67}$ See Jard v. Moon's Succession, I90 So. 867 (La. App. I939).

${ }^{68}$ See Paschal v. Acklin, 27 Tex. I73 (1863); Estate of Dwyer, 159 Cal. 680, I15 Pac. 242 (I91x); Estate of Lathrop, 165 Cal. 243, I3I Pac. 752 (1913); Estate of Gracey, 200 Cal. 482, 253 Pac. 921 (I927); Estate of Lanton, 217 Cal. 451, 19 P.2d 793 (1933); Decker v. Vrecland, 220 N.Y. 326, I15 N.E. 989 (19r7). As to the repercussions on the domiciliary administration, see In re Ogilvic, [1918] I Ch. 492; In re Lawrence's Will, 93 Vt. 424, I98 Atl. 387 (I9r9); Thompson v. Surrpe, 24 Pa. 474 (1855).

${ }^{00}$ E.g., Cal. Prob. Code $\$ 27$ (Supp. r95I); Ill. Rev. Stat. c. 32, $\$$ I81 (I953); Iowa Code $\$ 567.1$ (1954); ME. Rev. Stat. c. 54, \$5 (1954); MD. Ann. Code Gen. Laws art. 23, \$249 (I951); Minn. Stat. \$500.22 (1953); Neb. Rev. Stat. \$76-402 (1943); N. D. Rev. Code $\$ 56-0205$ (1943); Tex. Rev. Civ. Stat. Ann. art. 166 (1948); VA. Code $\$ 57-12$ (Supp. 1954); Curtis v. Maryland Baptist Union Ass'n, I76 Md. 430, 5 A.2d 836 (1939). 
of such prohibitions may be treated as rendering a disposition to the corporation invalid or as invalidating the continued holding. In the first event, the subjectmatter accrues to the heirs or to those who benefit from the lapse of a legacy or devise ${ }^{70}$ in the latter, it is often only the state that can intervene. ${ }^{71}$ In either event, the purpose of the testator's gift is frustrated. As mortmain laws are intended to limit the capacity of the corporation to receive or hold property rather than the dispositive power of testators, the law applicable is that which determines the powers of the corporation, ${ }^{72}$ which may be the law under which it is incorporated, or, in Europe, the law of the place of the main office, or, possibly, the law of the situs of the land devised. ${ }^{73}$ Consideration of this pitfall by the draftsman would seem necessary to avoid frustration of the testator's intention. ${ }^{\mathbf{7 4}}$

\section{Perpetuities, Accumulations, and Conditions}

The conflict-of-laws rules relating to the validity of dispositions questioned because of possibly invalid perpetuities, accumulations, or conditions are not sufficiently. developed to permit a firm statement to the effect that the law governing the succession generally shall determine these questions. In the Anglo-American jurisdictions, the decisions in the nontrust cases appear to indicate the usual choice-of-law reference to the situs of immovables and to the testator's domicile at death in the case of movables. ${ }^{75}$ Most of the problems of this type, however, have arisen in cases involving trusts, wherein alternative references to the usual governing law or to the law of the place of administration have been made to sustain validity. ${ }^{i 6}$ It is also indicated that an express choice-of-law clause in the trust instrument may permit the testator effectively to determine the governing law, if the law chosen has at least some reasonably close connection to the facts at hand. ${ }^{77}$ These results in the trust cases may well be extended to nontrust cases. For example, the policy

${ }^{70}$ See Kennett v. Kidd, 87 Kan. 652, I25 Pac. 36 (I912); Proctor v. Methodist Episcopal Church, So., 225 Mo. 51, 123 S.W. 862 (I909); Re McGraw, III N.Y. 66, I9 N.E. 233 (I888); Davidson College v. Chambers, 56 N.C. 253 ( 1857 ).

${ }^{71}$ See Bank of Commerce and Trust Co. v. Banks, I6I Tenn. II, 28 S.W.2d 340 (1930); Waters v. Order of the Holy Cross, 155 Md. 146, 142 Atl. 297 (1928); Hubbard v. Worcester Art Museum, I94 Mass. 280, 80 N.E. 490 (Ig07); Farrington v. Putnam, 9o Me. 405, 37 Atl. 652 (I897). See also Alger, Consequences of Illegal or Ultra Vires Acquisition of Real Estate by a Corporation, 8 Harv. L. REv. 15 (I894).

${ }^{72}$ But cf. Wolfe, op. cit. supra note $\mathrm{x}$, at 578 .

${ }^{73}$ Sce In re Lampson's Will, I6r N.Y. $5 \mathrm{Ir}, 56$ N.E. 9 (1900); Hollis v. Drew Theological Seminary, 95 N.Y. 166 (1884); cf. Kerr v. Dougherty, 79 N.Y. 327 (1879).

${ }^{7 t}$ Under some laws, an individual convicted of certain crime may be incapable of acquiring property by way of succession on death. See, e.g., French Penal Code art. 9(2) (52d ed., Dalloz 1955). Such a penal law, however, is unlikely to be applied in other states.

${ }^{75}$ See Dicey, op. cit. supra note I, at 829; Cheshare, op. cit. supra note $I$, at $533,557$.

${ }^{70}$ Sce, e.g., Shannon v. Irving Trust Co., 275 N.Y. 95, 9 N.E.2d 792 (1937); Matter of Chappell, 124 Wash. 128, 213 Pac. 684 (I923).

${ }^{77}$ See Wilmington Trust Co. v. Wilmington Trust Co., 26 Del. Ch. 397, 24 A.2d 309 (1942); Wilmington Trust Co. v. Sloane, 30 Del. Ch. I03, 54 A.2d 544 (I947); Application of New York Trust Co., 197 Misc. 598, 87 N.Y.S.2d 787 (Sup. Ct. 1949). See also WaLter W. LAND, Trusts in the Confuict of Laws II8 (1940); Cavers, Trusts Inter Vivos and the Conflict of Laws, 44 Harv. L. Rev. I61 (1930). 
behind the rule against perpetuities varies only slightly from state to state. ${ }^{78}$ The trust cases indicate that the choice-of-law reference which sustains the trust most often will be applied. ${ }^{79}$ The cases referring to the law of the place of administration point out that the policies behind the rule concern the place where the assets are to be administered..$^{80}$ It is possible, then, in cases of similar legal interests in movables, that a court could consider that the state of the location of the assets in the hands of the first taker would be the state most concerned, even though normally such a contact point is ignored.

Extreme caution must be used by the planner of an international estate in creating even the most familiar common-law future interests and trusts. While analogous institutions may be found in civil-law countries, the analogy may, in many instances, be misleading. ${ }^{81}$ Interests which are considered by a common-law court to be vested and free from questions of perpetuities may well be invalid under a civil-law restriction if postponed for more than ten, twenty, or thirty years. ${ }^{82}$ The trust is a concept nearly unique to the common-law countries, and attempted transition to civil-law substitutes is dangerous. ${ }^{83}$

The problem of the illegal or immoral condition remains to be mentioned. At the outset, it should be recognized that attitudes vary in different countries. What may seem reasonable in one place may be illegal or immoral in another. ${ }^{84}$ Consequently, attaching conditions calling for an individual to perform or desist in performing some act which relates to politics, marriage, or religion is of doubtful wisdom. For example, an attempt to impose upon foreign legatees a restraint opposed to prevailing political or religious attitudes in the country where the gift may have to be enforced is likely to result in its being stricken as contrary to public

${ }^{78}$ See Shannon v. Irving Trust Co., 275 N.Y. 95, 9 N.E.2d 792 (1937); Cross v. Unitcd States Trust Co. I3I N.Y. 330,30 N.E. 125 1892).

${ }^{79}$ See, e.g., Hope v. Brewer, 136 N.Y. 126, 32 N.E. 558 (1892). See also Note, Social Limitations on Wealth Disposition and the Conflict of Laws, 32 CoLuM. L. REv. 680 (1932).

${ }^{80}$ See, e.g., Amerige v. Atty. Gen., 324 Mass. 648, 88 N.E.2d 126 (1949); Matter of Chappcll, 124 Wash. 128, 213 P. 684 (1923); Curtis v. Curtis, 185 App. Div. 391, I73 N.Y. Supp. 103 (1st Dep't I9r8). See also Swabenland, The Conflict of Laws in Administration of Express Trusts of Personal Property, 45 YALE L. J. 438 (1936); Beale, Living Trusts of Movables in the Conflict of Lawus, 45 Hanv. L. Rev. 969 (I932).

${ }^{81}$ See P. J. Eder, Anglo Amfrican and Latin American Law i12 (1950); Wolfp, op. cit. supra note 1 , at 59r; of. In re Piercy, [1895] I Ch. 83.

${ }^{82}$ See EDER, op. cit. supra note $8 \mathrm{I}$, at 114 .

${ }^{83}$ See id. at 88; Pierre Georges Lepaulie, Traite theorjoue et praticue des trusts (1932), and Rheinstein, Book Review, 43 Yale L. J. ro49 (r934); Feilx Weiser, Trusts on the Continent of Europe (x936); Lepaulle, Civil Law Substitutes for Trusts, 36 YAL.E L.J. I126 (1926); Mayer, Trusts and Swiss Law, I INT'L \& Comp. L. Q. 378 (1952); Nussbaum, Sociological and Comparative Aspects of the Trust, 38 Cozdm. L. Rev. 408 (1938); Patton, Trust Systems in the Western Hemisphere, 19 Tuz. I. Rev. 398 (1945); Wuerdinger, The German Trtist, 33 J. CoMp. Leg. \& INT'L L. (3d ser.) 31 (I95I). The trust of the Anglo-American pattern has been introduced by modern legislation in the principality of Liechtenstein, Law of Jan. 20, 1926, art. 897-932a, as amended, Law of April 10, 1928, LiEchTENSTEInisches Zivilgesetsbuch, and Panama. See Alfaro, Trust and Civil Latv with Special Reference to Panama, 33 J. CoMp. Leg. \& INr'L L. (3d ser.) 25 (195I). By locating assets in these countries in trust, a properly advised draftsman may be able to achieve effects very similar to those of an American trust.

${ }^{83}$ Cf. WolfF, op. cit. supra note $\mathrm{I}$, at $180-85$. 
policy. The same, of course, is true in the United States, where public policy may be used to invalidate the gift (as when promoting illegal or immoral activity) ${ }^{85}$ or to invalidate the condition, leaving the gift absolute (as when restricting otherwise accepted freedom of activity).$^{86}$

If, however, the testator insists on a restriction that is subject to serious question in another state or country, there are ways of maneuvering assets and dispositions to approximate his wishes. One device is the creation of an inter vivos trust in a jurisdiction sympathetic to the settler's desires and the exclusion of the problem from the will altogether. In many instances, this may be the only possible way to avoid distortion of the testamentary scheme. Alternatively, some states, to a limited extent, have recognized the right of the testator to select the law applicable to testamentary dispositions. ${ }^{87}$ New York's statute, for example, provides that as to assets within New York, the testator may select the law of New York, notwithstanding his domicile. It may, thus, be advisable in this connection to move the testator's assets to one of these states and include such a choice-of-law provision in his will after making certain that his dispositions are valid by the law of that state. This latter qualification probably limits the perversion of these choice-of-law statutes to serve the grossly peculiar quirks of a testator's mind. And even with this freedom under a law such as the New York statute, the effect of such a bequest in other jurisdictions is questionable. The validity of such a provision may not be recognized in the courts of other states or countries, and it is possible that the distribution of assets there may be influenced by the distribution of New York assets in a manner contrary to that provided by the laws of the state or country in question. ${ }^{88}$ This is particularly possible if the other state or country is that of the domicile of the testator or of the testator and the beneficiary. ${ }^{89}$ In such a case, the draftsman must bear in mind that the testamentary scheme may be distorted by this retaliation in distribution. The safest way of handling the matter, therefore, is to make certain that all gifts comply with the different laws having possible application and to avoid dispositions of doubtful validity under the law of any one of the states having significant contact with the estate.

\section{Ademption and Lapse of Devisees and Bequests}

In addition to the post-execution contingencies previously discussed, such as

${ }^{85}$ See In re Scott's Will, 88 Minn. 386, 93 N.W. Io9 (1903); Hill v. Upper, IIg Wash. 62, 204 Pac. 1055, 207 Pac. 689 (I922).

${ }^{80}$ See Dwyer v. Kuchler, II6 N.J. Eq. 426, I74 Atl. I54 (Ch. I934); Tripp v. Payne, 339 Ill. I78, I7I N.E. I3I (I930); Meek v. Fox, II 8 Va. 774, 88 S.E. I6I (I9I6); Knost v. Knost, 229 Mo. I70, I29 S.W. 665 (I9I0); Hawke v. Enyart, 30 Neb. I49, 46 N.W. 422 (I890).

${ }^{87}$ Ilt. Rev. Stat. c. $3, \S 89 \mathrm{~b}$ (1953); Mich. Stat. ANn. $\$ 27.3178$ (II4a) (Supp. 1955); N. Y. D́Ec. Est. LAw $\$ 47$.

${ }^{88}$ See Caruso v. Caruso, 106 N.J. Eq. 130, 148 Atl. 882 (Ct. Err. \& App. 1930); Van Dykes Appeal, 60 Pa. $48 \mathrm{I}$ (1869); McGehee v. McGehee, 152 Md. 66r, I36 Adl. 905 (I927); cf. Bankers Trust v. Greims, r ro Conn. 36, r47 Atl. 290 (1929).

${ }^{80}$ See Griley v. Griley, 43 So.2d 350 (Fla. 1949), Murphy v. Murphy, I25 Fla. 855, I7o So. 856 (1936); In re Lawrence's Estate, 93 Vt. 424, ro8 Atl. 387 (I919); Cummings' Estate, 153 Pa. 397,25 Atl. II25 (1893); In re Olgilvie, [I918] I Ch. 492. 
revocation by operation of law on subsequent marriage or divorce, the draftsman must anticipate many other changes in circumstances. If the draftsman does not foresee the contingencies that may arise after the execution of a testamentary instrument, the testamentary scheme may well be distorted. It may happen that a beneficiary predeceases the testator, or that the subject matter of a legacy no longer belongs to the testator's estate at the time of his death, or that the estate is insufficient to pay all legacies or debts. Unless the will specifically provides for such contingencies, the courts apply rules which are held in store for such cases. ${ }^{00}$ These rules, which may be aptly described as rules of stop-gap law, vary among jurisdictions. If a legatee predeceases the testator, the legacy may lapse under the law of one jurisdiction ${ }^{91}$ but accrue to the benefit of certain other individuals under the law of another. ${ }^{92}$ If surprises are to be avoided, the draftsman should consider these stop-gap rules in the jurisdictions likely to be concerned with the testator's estate.

The Anglo-American conflict-of-laws decisions on ademption and lapse of dispositions have consistently applied the traditional succession references. ${ }^{83}$ For example, a lapse of a devise of land is determined by the law of the situs, and lapse of a bequest of movables by the law of the testator's domicile at death. Ademption of a devise of land, likewise, has been controlled by the situs of the land purportedly devised by the will; ademption of a bequest by the law of the domicile of the testator at death. In civil-law countries, too, the law applied is commonly that by which the course of the succession is determined in general, including, of course, the renvoi rules. ${ }^{94}$

There have been few variations, but three possible approaches may raise some doubt as to the wisdom of blind reliance on these so-called settled rules. Consider, for example, the case of a bequest to a legatee who resides elsewhere than at the testator's domicile, where the legatee predeceases the testator, but the legatee's will disposes of his residuary to someone other than his intestate successors. The usual rule would apply the law of the testator's domicile to determine if there is a lapse.

${ }^{90}$ See Ashburner v. Macquire, 2 Bro. C. C. 108, 29 Eng. Rep. 62 (1786); Owen v. Busiel, 83 N.H. 345, I42 Atl. 692 (I928); Harvard Unitarian Soc'y v. Tufts, 15I Mass. 76, 23 N.E. 1006 (1890); Morehouse v. Bridgeport City Trust Co., I37 Conn. 209, 75 A.2d 493 (1950); In re Spier's Estate, 224 Mich. 658, r95 N.W. 430 (1923); In re Hall's Estate, I83 Cal. 6r, I90 Pac. 364 (1920); May v. Burns, 222 Ala. 68, 13x, So. 232 (1930). See also Mechem, Specific Legacies of Unspecific Things, 87 U. PA. L. Rev. 546 (1939); Page, Ademption by Extinction, I943 Wis. L. REv. II; Warren, History of Ademption, 25 Iowa L. Rev. 290 (1940); Mechem, Problems Under Anti-Lapse Statutes, 19 Iowa L. Rev. I (1933).

${ }^{22}$ E.g., a bequest to a sister who predeceased the testator would lapse under a statute referring only to descendants of the testator. See, e.g., Als. Code tit. 6I, $\$ 16$ (I940); Ariz. Code Ann. $\$ 4$ I-109 (1939).

${ }^{92}$ E.g., a bequest to a deceased sister would not lapse under a statute referring to any legatees or to any kindred. See, e.g., CAL. ProB. Code $\$ 92$ (I949); VA. Code $\$ 64-64$ (I950).

${ }^{83}$ In re Dublin's Estate, $375 \mathrm{~Pa}$. 599, roI A.2d 731 (I954); Phillips v. Phillips, 213 Ala. 27, 104 So. 234 (1925); Lowndes v. Cooch, 7 Md. 478, 39 Atl. 1045 (1898); In re Cohn, [1945] Ch. 5; In re Cunnington, [1924] I Ch. 68. See Note, Anti-Lapse Statutes and the Conflet of Laws, 47 Yale L. J. I2r6 (1938). Cf. Eisenschenk v. Fowler, 82 So.2d 876 (Fla. I955).

${ }^{\text {os See note }} 48$ supra et seq. 
If the testator's domicile has an antilapse statute, the gift goes over to the legatee's estate, ${ }^{95}$ or lineal descendants, ${ }^{96}$ or passes as if the legatee survived the testator, ${ }^{97}$ depending on the particular lapse statute in effect. Who can claim and under what law? The variation in lapse statutes suggests the possibility that while the testator's domicile determines that there is no lapse, the domicile of the legatee may determine the identity of the person who takes the bequest as substituted legatee. This would bring into operation a law not included within the traditional conflict-of-laws references. $^{98}$

A second situation that may raise some doubt as to the settled nature of the conflict rules relating to ademption is that in which the testator includes in his will a devise of land in a state other than his domicile, but conveys it away prior to his death. Most of the statutes preventing ademption are drafted in terms of contracts to convey, but some have been extended to the situation in which the land has been conveyed.99 The usual choice-of-law rule permits the questions to be determined by the law of the situs. ${ }^{\mathbf{1 0 0}}$ This works well when the land is still in the testator's estate, though subject to a contract to sell. However, determining the disposition of a testator's assets by the law of the situs of land previously conveyed and no longer in the estate seems questionable. This is particularly so if the proceeds of the sale are located in another state which would characterize them as movables.

A third qualification may be suggested on the basis of two strong policies in the area of testation. The doctrines preventing lapse and ademption are subject to the testator's intention. There is considerable authority and some reason to determine questions of intention by the laws of either the testator's domicile at the time of execution of the will or the place of execution, rather than by the law of his domicile at death. ${ }^{101}$ In addition, the statutes preventing lapse and ademption are probably responsive to family protection policies applicable to succession and are a means of protecting the descendants of legatees who are close members of the testator's

${ }^{0 t}$ See, e.g., Matter of Penrose, 164 Misc. 388, 299 N.Y. Supp. 844 (Surr. Ct. I937); cf. R. I. Gen. LAws c. $566, \$ 30(1938)$.

${ }^{00}$ See, e.g., S. D. CODE $\$ 56.0232$ (1939); Ill. Rev. Stat. c. 3, $\$ 49$ (1953).

${ }^{07}$ Sce, e.g., ME. REv. STAT. c. I69, \$ 1o (1954).

${ }^{98}$ See, e.g., the complications as to this in Matter of Penrose, 164 Misc. 388, 229 N.Y. Supp. 844 (Surr. Ct. 1937). This law of the legatee's domicile may be contemplated in an application of renvoi doctrines. Cf. Matter of Battell, 286 N.Y. 97, 35 N.E.2d 913 (1941); In re Winslow's Estate, 138 Misc. 672,247 N.Y. Supp. 506 (Surr. Ct. 1930).

${ }^{00}$ See, e.g., Phillips v. Phillips, 213 Ala. 27, 104 So. 234 (1925); cf. Dwyer's Estate, 159 Cal. 664, II5 Pac. 235 (I9II).

${ }_{100}$ See, e.g., Phillips v. Phillips, supra note 99.

${ }^{101}$ Higinbotham v. Manchester, 113 Conn. 62, 154 Atl. 242 (1931); Houghton v. Hughes, ro8 Me. 233, 79 Atl. 909 (19II); Keith v. Eaton, 58 Kan. 732, $5 \mathrm{I}$ Pac. 27I (1897); Staigg v. Atkinson, 144 Mass. 564, 12 N.E. 354 (1887); Matter of Dialogue, 159 Misc. $x 8,287$ N.Y. Supp. 237 (Surr. Ct. x936); CHeshrRE, op. cit. supra note $\mathrm{I}$, at 562-66. See also Herring, Is the Construction of Wills Devising Real Estate Governed by the Rules of Construction of the Domicile of the Testator or by the Rules of Situs of the Property?, 4I AM. L. ReG. (n.s.) 623 (1902). 
family. ${ }^{102}$ This suggests that the state of the testator's domicile at death well could be considered the state having the dominant interest in the family, and, consequently, that its policy should determine lapse and ademption questions in cases of immovables as well as movables.

It is fortunate that the problems of ademption and lapse are subject to expressions of the testator's intention, for, this is the only reasonably safe solution. The draftsman should cover the matter in the testamentary instrument by setting out wellformulated rules for these various foreseeable contingencies. It is also possible that an express, choice-of-law clause would incorporate by reference a governing law under the intention doctrine. While this latter method may be effective, it probably is less safe than setting out a lapse and ademption clause in the will.

\section{Terms of Special Meaning and Their Construction}

Another problem of determining the intention of the testator is raised when the testator uses words of special meaning. For example, in a gift to "the children of $\mathrm{X}$," the term "children" may or may not include any of the following categories of individuals: legitimate children, illegitimate children, grandchildren, adopted children, legitimated children, foster children, recognized illegitimate children, etc. The meaning given to the term may vary from jurisdiction to jurisdiction. The same observation applies to such terms as "my money," "my effects," "to the heirs of," "die without issue," "heirs," or "issue," and the like. It is often indicated that the law governing the succession will determine these questions of construction; ${ }^{103}$ nevertheless, there are deviations from the traditional rules. For example, it may be urged that the "heirs" or "children" of a legatee are to be determined by the personal law of the legatee rather than the law generally determining the course of the succession. ${ }^{104}$ Likewise, many courts have used the law of the testator's domicile at the time of execution rather than at death to determine such questions. ${ }^{105}$ In any case of a single will, the concept of a universal disposition may cause the situs to prefer the law of the last domicile on such questions. ${ }^{106}$ The existence of these possibilities indicates that the predictability of the result is questionable.

In all such cases, therefore, it is necessary for the draftsman to consider the meaning which is given to such terms by the rules of authoritative explanation of every jurisdiction in question. The alternative is the difficult one of so clearly

${ }^{102}$ This at least appears to be an important policy in the statutes referring to children or lincal descendants of the testator. See, e.g., Ill. Rev. Stat. c. 3, \$49 (I953); Ind. AnN. Stut. \$6-60I (Burns 1953).

${ }^{103}$ E.g., Simmons v. O'Connor, I49 S.W.2d I107 (Tex. Civ. App. 194I); Pect v. Peet, 229 Ill. 3.4r, 82 N.E. 376 (1907); Jennings v. Jennings, 21 Ohio St. 56 (187I); see In re Osborn's Estate, 15I Misc. 52, 270 N.Y. Supp. 6I6 (Surr. Ct. 1934). See also Casner, The Construction of Gifts to "Heirs" and the Like, 53 Hanv. L. Rev. 207 (r939).

zo: See note 88 supra.

105 See note ror supra.

${ }^{100}$ See WolfF, op. cit. supra note $x$, at 59x; cf. In re Peabody's Estate, Irs N.Y.S.2d 337 (Sup. Ct. I952); In re Ruperti's Estate, I94 Misc. 376, 86 N.Y.S.2d 887 (Surr. Ct. 1949); In re Bernie's Estate, 74 N.Y.S.2d 887 (Surr. Ct. 1947); Matter of Gato, 276 App. Div. 651, 97 N.Y.S.2d 171 (1st Dep't 1950). 
defining these terms that no controversy can conceivably arise with respect to their meaning.

\section{Gifts to Aliens or Residents of Foreign Countries}

Different governmental attitudes regarding taxation, inheritance, and private property in other countries may often intervene to thwart the accomplishment of the testator's intention. There appears to be serious question whether beneficiaries living in some foreign countries would ever receive the benefit of a bequest, even if sent to them, because of governmental confiscation under nationalization acts, foreign exchange controls, or the guise of taxation. ${ }^{107}$ This danger is not limited to foreign nationals, but will apply to United States citizens as well where foreign currency controls provide for redemption of foreign credits at reduced rates of exchange ${ }^{108}$ or where there is doubt that even a check will reach an addressee. ${ }^{109}$ Particular difficulties can arise when the intended beneficiary is a citizen or resident of a country which becomes involved in war with the United States. In such cases, the bequest may simply be forfeited to the United States Alien Property Custodian. ${ }^{110}$

In most of these situations, therefore, it would seem advisable to establish a trust with sufficient discretion and directions to the trustees to provide for alternative dispositions in the event such obstacles to distribution should arise. Such alternative dispositions would also avoid the impounding of such bequests, as is possible under statutes in several of our states, ${ }^{111}$ but would enable some program of the testator to be carried out.

In any case in which assets are located abroad, or where a beneficiary is a citizen or resident of a foreign country, or even when the testator himself is an alien or resident of a foreign country, it is indispensable for the draftsman to find out whether any treaty exists between the United States and the country in question and what any such treaty provides with respect to decedents' estates. ${ }^{112}$ While the treaty may

${ }^{107}$ See Petition of Mazurowski, 33I Mass. 33, II6 N.E.2d 854 (x954); In re Url's Estate, 7 N.J. Super. 455, 71 A.2d 665 (County Ct. 1950); In re Mucl:l's Estate, 174 Misc. 35, 19 N.Y.S.2d 1009 (Surr. Ct. 1940); In re Bold's Estate, 173 Misc. 545, I8 N.Y.S.2d 291 (Surr. Ct. 1940); In re Landau's Estate, 172 Misc. $65 \mathrm{x}$, I6 N.Y.S.2d 3 (Surr. Ct. 1939); In re Blasi's Estate, 172 Misc. 587, 15 N.Y.S.2d 682 (Surr. Ct. 1939); In re Weidberg's Estate, I72 Misc. 524, I5 N.Y.S.2d 252 (Surr. Ct. 1939).

${ }^{108}$ Cf. Petition of Mazurowski, sitpra note 107.

${ }^{100}$ See 3 I C.F.R. $\$ 2$ Ir.3 (Supp. 1955), where it is provided: "Withholding of delivery of checks or warrants. (a) The Secretary of the Treasury hereby determines that postal transportation, or banking facilities in general or local conditions in Albania, Bulgaria, Communist-controlled China, Czechoslovakia, Estonia, Hungary, Latvia, Lithuania. Poland, Rumania, the Union of Soviet Socialist Republics, the Russian Zone of Occupation of Germany, and the Russian Sector of Occupation of Berlin, Germany are such that there is not a reasonable assurance that a payee in those areas will actually receive checks or warrants drawn against funds of the United States, or agencies or instrumentalities thereof, and be able to negotiate the same for full value."

${ }_{110}$ Trading With Enemy Act, 40 STAT. 4I5 (Ig17), 50 App. U.S.C. $\$ 6$ (1952). See also World War II Alien Property Custodian Regulations, Exec. Order No. 9095, 7 FEd. Reg. 197I (1942), as amended, Exec. Order No. 9193, 7 id. at 5205 (1942), Exec. Order No. 9567, 1o id. at 6917 (1945).

${ }^{111}$ E.g., N.J. StAT. AnN. $\S 3$ A: 25-10 (r953); N.Y. Surr. CT. Act. $\$ 269$ (as amended 1939); Mass. GeN. Laws C. 206, $\$ 27 A$ (as amended 1950).

${ }^{112}$ Cf. S. A. Baytch, Conflict Law in the Unted States Treaties 82 (1955); Hyning, Treaty Law for the Private Practitioner, 23 U. CHI. L. REv. 36 (1955). 
not determine how property will be disposed of, it may well indicate the limits of testation or grant the foreign consular officials rights to represent the foreign citizen in our courts. In the latter event, the difficulty of avoiding confiscation by the foreign government may be increased.

\section{IV}

\section{Probate and Administration}

\section{A. Preliminary Observations}

Every legal system has to provide some kind of proceedings by which the genuineness and validity of an instrument purporting to be the will of a decedent can authoritatively be ascertained. While both probate and adminstration, as we know them, are institutions peculiar to the common law, numerous civil-law countries also provide machinery for the authoritative determination of heirship, testate and intestate. However, under the traditional civil-law approach, it is not necessary for a will first formally to be admitted to public record before it is used for legal purposes. Although this traditional approach has been modified widely and in several different ways, it is important for the American lawyer to know that in the case of a foreign decedent having assets in this country, it may not always be possible to procure that kind of official document which would correspond to the decree of probate of a court of a common-law jurisdiction.

Administration of an estate by an executor can, in all civil-law countries, be ordered in his will by any testator. ${ }^{113}$ A testator is likely to do so if he expects that the winding-up of his estate will present special difficulties. But where administration has not thus been provided for by the testator, it will not take place unless it is necessitated by extraordinary conditions, such as insolvency of the estate or justified reason to doubt the heir's reliability or ability properly to wind up the estate. In the regular course of events, title to all assets of the estate, both real and personal, passes directly from the decedent to his "heir" or "heirs." In the case of intestacy, the heirs are those persons who are so indicated by the intestacy statute of the country in question. In the case of testate succession, no exact common-law counterpart

${ }^{113}$ For the civil law analogues to probate and administration, see Rheinstein, Etropean Methods for Liquidation of Debts of Deceased Persons, 20 lowa L. REv. 43I (1935); Foreign Law Series No. 4, Administration of Estates in England, U.S.A., and France with Respect to Assets Abroad (1935); L. T. Bates, French Probate and Administration Practice in Relation to Estates of American Decedents (I931); E. L. Burgin, Administration of Foreign Estates (I931); H. Emimerich, Estate Practice in the United States and Europe (x950); P. Pellerin, The Frencil law op Wills, Probate, Administration, and Death Duties of the Estates of English Decedents leaving Prop. ERTY IN FRANCE (3d ed. 1933); Ballin, Disposal over German Estates by a British Executor, $18 \mathrm{~J}$. CoMp. LeG. \& INT'L LAW 289 (1936); Baty, Probating a Foreign Will, L. MaG. \& Rev. 220 (1913); Brown, French Practice of Administration of Estates, 3 INT'L \& CoMp. L. Q. 624 (1954); Wormscr and Burchard, Administration of German Decedents' Estate, 83 U. PA. L. Rev. 37 (1934); Artiun Nussbaum, American-Swiss Private International Law (Bilateral Studies in Private International Law No. I, I95I); Georges R. Delaume, American-French Private International Law (Bilateral Studies in Private International Law No. 2, I953); R. D. Kollewijn, Amertcan-Dutch Private International Law (Bilateral Studies in Private International Law No. 3, I955); Martin Domke, AmsericanGerman Private Law Relattons (Bilateral Studies in Private International Law No. 4, 1956). 
exists to those persons who are called "heirs" in the civil law. The closest commonlaw equivalent to the civil-law heir is our residuary legatee. Those persons whose status corresponds to that of general or specific legatees or devisees usually have but personal claims against the heir or heirs.

The duty to pay the debts of the decedent is incumbent upon the heir. If the assets of the estate are insufficient, he has to pay from his own pocket. To avoid this potentially grave responsibility, two alternatives are open to the person who is called to heirship by the intestacy law or the will. He can refuse to accept the heirship, which then devolves upon the person next in order. The declaration of refusal to accept heirship is usually required to be made in a notarial instrument and to be filed with the proper court. If heirship is declined by all persons successively called, it ultimately devolves upon the state, which is never liable for the debts, however, beyond the value of the assets actually received.

If the person called to heirship has accepted or simply failed timely to refuse acceptance, he can still limit his liability to either the assets of the estate or to their money value. All he had to do for this purpose under the Corpus Juris was to make an inventory of the estate and file it with the proper court. Such is still the law in many countries, especially those following the pattern of the French Civil Code. But under the German Code and those others which follow its model, the heir has to ask the proper court to initiate formal proceedings of administration and then hand over the assets of the estate to the administrator who will be appointed by the court. Administration of this kind will, of course, occur but rarely.

Exceptions to the general scheme exist in Austria and several other countries, where, as a general rule, every estate has to go through administration under the control of a court or other public agency. Under the impact of common-law influences, administration of the Anglo-American pattern takes place as a regular feature of succession in South Africa and Rhodesia, as well as in Quebec.

The American attorney who has to draft a will intended to affect assets situated in civil-law jurisdictions should, thus, consider that the treatment of these assets may differ considerably from that which he may be inclined to regard as the only possible one. Because of the direct passing of the title to the heir or heirs, conflict problems of administration will not arise as regularly as they do in common-law countries. But if there arises a problem of liability for debts or taxes, it is likely to be complicated. Systematic investigation of administration problems in the relation to civil-law countries has hardly been undertaken so far. The following discussion will, thus, concentrate upon the problems arising among common-law jurisdictions.

\section{B. Place of Administration}

Conflict-of-laws problems incident to the administration of a decedent's estate nearly always arise because of the location of assets within a particular state or nation. If a person owns property in a particular jurisdiction, he must face the possibility of administration being required there after his death. Thus, it becomes 
important to know where assets are subject to being administered, and then some attempt can be made to discuss ways of reducing the possibilities of administration at more than one place.

The location of land, for the purposes of administration, is mostly easily determined. The immovable must be administered or not administered by the law of the situs. ${ }^{114}$ The initial problem of characterization of the document of title or contract asset will come before the court within whose territorial jurisdiction the document or parties are located. But even here, if the interest is characterized as being an immovable, the situs law will govern $;^{115}$ and ultimately some action may be required at the situs, if only to take the necessary steps to make the record reflect the status of the asserted ownership. ${ }^{116}$

The location of movables, for the purpose of administration, is more complicated. A chattel is generally subject to the law of administration of the place where it happens to be located at the time the decedent dies. ${ }^{117}$ Often the law of a particular jurisdiction will permit the removal of assets without administration if they are only temporarily within the state and the removal is to the state of the decedent's domicile or the place where the chattel in question is customarily kept. ${ }^{118}$

The problem of determining the place of administration of intangibles probably has the most significance for estate planners, since the bulk of wealth is usually represented by intangible assets. In the United States, nonnegotiable debts and causes of action are subject to administration as assets of the estate wherever jurisdiction over the defendant debtor can be obtained for purposes of suit to collect. ${ }^{110}$ Location of an estate debtor or the debtor's property, for jurisdictional purposes, is a matter scarcely within the control of the decedent and peculiarly beyond the reach of the estate planner. The possible places of administration of intangibles represented by negotiable instruments or specialties are, however, subject to more definite control and prediction. ${ }^{120}$ This is probably also the case of corporate shares. Those interests which are chattelized in the paper representing them, to such an extent that the paper embodies the interest for most ownership purposes, are gen-

${ }^{114}$ E.g., Prescott v. Durfee, 13I Mass. 477 (188I), Sprayberry v. Culberson, 32 Ga. 299 (1861).

${ }^{115}$ See, e.g., In re Berchtold, [1923] I Ch. 192; In re Cutcliffe's Will Trusts, [1940] I Ch. 565. It may be that the characterization will have to be made according to the law of the situs of the land involved in the transaction. See Clarke v. Clarke, 178 U.S. I86 (1900); WolfF, op. cit. slipia note 1 , at 504, 570 .

${ }_{110}$ Cf. Fall v. Eastin, 215 U.S. I (1909); Matson v. Matson, I86 Iowa 607, 173 N.W. 127 (1919). See also Mallette v. Scheerer, I64 Wis. 415,160 N.W. 182 (1916).

${ }^{117}$ Cf. Morrison v. Hass, 229 Mass. 514, I18 N.E. 893 (1918); Cox v. Kansas City, 86 Kan. 298, 120 Pac. 553 (1912); Parnell v. Thompson, 8I Kan. 119, I05 Pac. 502 (1909).

${ }^{118}$ E.g., Christy v. Vest, 36 Iowa 285 (1873). See also Goodrich, op. cit. supra note 1, at 537.

${ }^{110}$ Furst v. Brady, 375 Ill. 425, 31 N.E.2d 606 (1940); Gordon v. Shca, 300 Mass. 95, 14 N.E.2d ro5 (1938); State ex rel C. B. \& Q. R. Co. v. Probate Court, 149 Minn. 464,184 N.W. 43 (1921); Saunders v. Weston, 74 Me. 85 (1882); see also Harris v. Balk, 198 U.S. 215 (1905); cf. Rheinstein, Die inlaendische Bedeutung einer auslaendischen Zwangsvollstreckung in Geldforderungen, 8 ZeIrscuRIrT F. Ausz. U. Intern. Privatrecht 277 (1934).

${ }^{120}$ See Smith v. Normart, 5I Ariz. 134, 75 P.2d 38 (1938); Lang's Estate, 301 Pa. 429, 152 Atl. 570 (1930); Toner v. Conqueror Trust Co., 131 Kan. 65I, 293 Pac. 745 (1930); Iowa v. Slimmcr, 248 U.S. 115 (1918). 
erally subject to administration where the paper is located. ${ }^{121}$ The paper is subject to the owner's control and its location most easily planned. Corporate shares are usually, but not always, completely transferable by endorsement and delivery of the certificate. ${ }^{122}$ If transferable only on the books of the corporation, the traditional conflicts rule permits administration at the place of incorporation of the issuing company. ${ }^{123}$ Since the location of assets is the most useful variable for the estate planner, it is well to keep the location possibilities in mind as various problems of administration are discussed.

Initial administration should be started at the domicile of the deceased, except in rare cases. The domicile is usually the one place at which a will can be probated, even though there are no assets within the jurisdiction of the domiciliary court. ${ }^{\mathbf{1 2 4}}$ Prompt administration at the domicile may be important for several purposes. First, the domiciliary personal representative is often entitled to preference in appointment in other states as ancillary administrator. Second, the domiciliary probate and construction of the will is often decisive of similar questions elsewhere. Third, prompt action by the domiciliary personal representative may make it possible to avoid administration in other states. Fourth, the principal administration at the domicile usually receives surplus movable assets from ancillary administrations for purposes of final distribution to the ultimate beneficiaries.

The significance of the domicile in estate planning is such that any circumstances suggesting the possibility of dual findings of domicile should be avoided. This not only precludes the probate confusion of conflicting findings of domicile, ${ }^{125}$ but also the problems of potential double taxation, such as arose in the Dorrance case. ${ }^{126}$

${ }^{121}$ Restatement, Conflict of Laws $\$ 477$ (1934); Lohman v. Kansas City So. Ry., 326 Mo. 868, 33 S.W. $2 d 117$ (1930); Griswold v. Kelly-Springfield Tire Co., 94 N.J. Eq. 308, I20 Atl. 324 (Ch. I916); Lockwood v. United States Steel Corp., 209 N.Y. 375, 103 N.E. 697 (1913), In re Miller's Estate, go Kan. 819, ${ }_{3} 6$ Pac. 255 (1913); Russell v. Hooker, 67 Conn. 24, 34 Atl. 7 II (1895). Contra, Kennedy v. Hodges, 215 Mass. 112, ra2 N.E. 432 (1913); Gamble v. Dawson, 67 Wash. 72, r20 Pac. ro6o (rgr2); Murphy v. Crouse, I35 Cal. 14, 66 Pac. 971 (1901); Grayson v. Robertson, 122 Ala. 330, 25 So. 229 (I899); cf. Crane v. Crane, 373 Pa. I, 95 A.2d 199 (I953); Krizanek v. Smith, 32 Del. 513, 87 A.2d 871 (1952). See also Goodrich, op. cit. supra note 1, at 545-48; Dicey, op. cit. stupra note 1, at 305; Cheshrre, op. cit. stupra note $\mathrm{I}$, at 510 . For a thorough discussion, see Hopkins, Conflict of Laws in Administration of Decedents' Intangibles, 28 Iowa L. Rev. 422, 613 (1943); Pomerance, The "Situs" of Stock, i7 Conneli L. Q. 43 (I93I).

${ }^{222}$ The Uniform Stock Transfer Act has been adopted by all the states in the United States. See 6 U.L.A. 6 (Supp. 1955).

${ }^{123}$ Albuquerque Nat'l Bk. v. Citizens Nat'l Bl.., 212 F.2d 943 (5th Cir. 1954); Kennedy v. Hodges, 215 Mass. 212, 102 N.E. 432 (1913).

${ }^{124}$ Sce Wolf v. Gills, 96 Okla. 6, 2 I9 Pac. 350 (x923); Holburn v. Pfanmiller's Adm'r, II 4 Ky. 83I, 7I S.W. 940 (1903); cf. Flath v. Neal, 63 Ariz. 68, 159 P.2d 617 (1945). See also WolfF, op. cit. stipra note I, at 606; Dickr, op. cit. supra note I, at 302; Cheshire, op. cit. supra note I, at 508.

${ }_{125}$ See Riley v. New York Trust Co., 315 U.S. 343 (1941); Baker v. Baker, Eccles \& Co., 242 U.S. 394 (I917); Overby v. Gordon, I77 U.S. 214 (1900).

${ }_{125}$ The Dorrance litigation is reflected in the following opinions: Hill v. Martin, 296 U.S. 393 (1935); In re Dorrance's Estate, II6 N.J. Eq. 204, 172 Atl. 503 (Prerog. Ct. 1934); In re Dorrance's Estate, II 5 N.J. Eq. 268, I70 Atl. 6or (Prerog. Ct. 1934); In re Dorrance's Estate, 309 Pa. 151, I63 Atl. 303 (1932); New Jersey v. Pennsylvania, 287 U.S. 580 (1932). See also, Texas v. Florida, 306 U.S. 398 (1939); Worcester County Trust v. Riley, 302 U.S. 292 (1937). The problem is explored in the article by Twed and Sargent, Death and Texes are Certain-but What of Domicile?, 53 Harv. L. REv. 68 (1939). 
In this regard, the concept of domicile, as understood in the laws of the different jurisdictions involved, should be considered. If the client is unable or unwilling to arrange his personal and family affairs to avoid the problem of dual domicile, at least his assets should be so located as to mitigate the effect of the possible conflicting finding. For example, if confronted with the situation in the Dorrance case, it would be preferable to have nearly all the assets located in one of the "domiciliary" states, preferably that state with the stronger claim-and perhaps the lower tax rate. ${ }^{127}$ Since the impasse in binding two states to one finding of domicile can be avoided by getting the two states to litigate in the same court, voluntary tax payments probably should not be made. Rather, the state which has insufficient assets to cover its tax claim should be forced to sue in the courts of the other. In such a case, the concept of submission to jurisdiction is effective, and the one domicile determination probably binding at least as to the major portion of the assets. ${ }^{128}$ If the state without assets does not take prompt action in the courts of the state having assets, distribution of the assets by the latter court would probably protect the distributees under doctrines of due process and full faith and credit. ${ }^{120}$

In regard to the problem of multiple taxation, reciprocal exemption statutes have been adopted in most of the states of the United States, and treaties offer substantial protection in the international area. ${ }^{130}$ In either case, the statute or treaty must, of course, be considered in anticipating the post-mortem effect of dispositions and the location of the testator's assets.

Even without regard to the problems of taxation, there is considerable reason to avoid multiple administrations. Consequently, the estate owner must, as he handles his affairs during life, constantly be aware of the problems that may possibly be occasioned by the location of his assets. When faced with the fact of location of assets in different jurisdictions after the testator's death, however, there are still some opportunities open for avoiding ancillary administration. If possession of nondomiciliary assets can be obtained by the domiciliary personal representative by voluntary surrender or payment before ancillary administration is begun, the courts will probably recognize such payment, and the jurisdictional basis for ancillary administration is removed. ${ }^{131}$ Since administration is usually in the hands of some-

\footnotetext{
${ }^{122}$ It may be" more of an advantage to have substantial assets in neither "domiciliary" state and to force both to claim assets in a third, neutral forum. This would be a highly unusual situation in the location of assets.

${ }^{128}$ See Matter of Trowbridge, 226 N.Y. 283, r94 N.E. 756 (1935). See also, Curry v. McCanless, 307 U.S. 357 (I939); Matter of Benjamin, I76 Misc. 518, 27 N.Y.S.2d 948 (Surr. Ct. I94I), aff $d$, 263 App. Div. 981, 34 N.Y.S.2d 394 (Ist Dep't 1942), aff'd, 289 N.Y. 5;4, 43 N.E.2d 531 (1942). ${ }^{129}$ See Tilt v. Kelsey, 207 U.S. 43 (1907); Overby v. Gordon, I77 U.S. 214 (1900).

${ }^{130}$ Statutes have been adopted in thirty-two states providing for reciprocal exemption of intangible personal property of nonresident decedents. See P-H INH. \& TRans. Tax SERv. 9 851 (1956). Treatics designed to avoid multiple estate taxation in the international area are in effect between the United Statcs and Australia, Belgium, Canada, Eire, Finland, France, Greece, Italy, Japan, Norway, Switzerland, the Union of South Africa, and the United Kingdom. See 4-A P-H I956 FED. TAX SEnv. I I28,0II.

${ }^{131}$ See Maas v. German Savings Bank, I76 N.Y. 377,68 N.E. 658 (1903); Wilkins v. Ellett, 108 U.S. 256 (1883); cf. Petersen v. The Chemical Bank, 32 N.Y. 21 (1865); Leake v. Gilchrist, 13 N.C. 48, 2 Dev. 73 (1830); Grignon v. Shope, roo Ore. 611, 197 Pac. 317 (1921). Sce also Beale, Voluntary
} 
one sympathetic to the efficient administration of the whole estate, it is often only necessary to persuade debtors of the estate to pay without suit and to persuade persons interested in the estate not to petition for ancillary letters. Prompt assurance to creditors of fair treatment of their claims, if filed at the domicile, will usually be sufficient to prevent them from petitioning for ancillary administration. ${ }^{132}$

Voluntary payment or collection of assets is not the only means of avoiding ancillary administration. Some states authorize foreign personal representatives to sue in their courts if no local administration has been taken out. ${ }^{133}$ This procedure enables the domiciliary personal representative to proceed with interstate liquidation, even if the parties are unwilling to settle the matter voluntarily. Wider adoption of these statutes would enable considerable savings of time, money, and effort in multistate administration. It must, of course, be borne in mind that whatever is done must be in accordance with the law of the place where the assets in question are located. This means that a thorough consideration of the administrative statutes of each such jurisdiction is indispensable in multistate administration. When assets are located in a foreign country or left by a foreign national in the United States, treaties may provide direction, or the consular officials of the country of the decedents' domicile or nationality may be entitled to administer. ${ }^{134}$

If ancillary administration is necessary, the domiciliary representative should apply for it. Under the statutes of many states, the domiciliary administrator will be entitled to priority in appointment. ${ }^{\mathbf{1 3 5}}$ Having the same person administering the estate in different jurisdictions aids in handling the assets as a unit in the manner intended by the testator. Because of limitations upon corporate fiduciaries or others, or because of the state's policy to provide business for its public administrator, however, it may not be possible to have the same representative in each jurisdiction, ${ }^{136}$ but sympathetic representatives having a common interest are most beneficial.

\section{Proof of Will and Contests}

In the testamentary estate, the will should ordinarily first be probated at the domicile. Admission of the will to probate at the domicile usually precludes contests

Payment to a Foreign Administrator, 42 Harv. L. Rev. 597 (1929); Mersch, Voluntary Payment to Foreign Administrator, 18 GEo. L. J. 130 (1930). But see WoLFF, op. cit. stupra note 1 , at 607 as to the English authorities.

${ }^{132}$ See Putnam v. Pitney, 45 Minn. 242, 47 N.W. 790 (189x); cf. In re Williams' Estate, I30 Iowa 553, I07 N.W. 608 (I906); Colo. Rev. Stat. \$152-6-5 (1953); Fla. STAT. $\$ 734.30$ (3) (4) (1953); Ill. Rev. StaT. c. 3, \$262 (r953).

${ }_{133}$ E.g., Colo. Rev. Stat. $\$ 152-6-4$ (1953); Fla. Stat. $\$ 734-30$ (2) (3) (I953); Ill. Rev. Stat. c. $3, \$ 265$ (1953). But see WoLFF, op. cit. supra note 1 , at 607 , as to the English practice.

134 See, e.g., treaties with: Argentina, July 27, I853, art. IX, Io Stat. I009; Austria, June I9, I928, art. IV, 47 Stat. I879; Germany, Dec. 8, 1923, art. IV, 44 STAt. 2135; Great Britain, March 2, I899, art. I, II, III, 3r Stat. I939; and Italy, Feb. 2, I948, art. II, III, IV, 63 Stat. 2258. See also Hynning, Treaty Law for the Private Practitioner, 23 U. CH. L. Rev. 36, 73 (1955); Bayrtar, op. cit. sipra note 112 .

${ }_{135}$ E.g., ARK. Stat. ANn. $\$ 62-3104$ (Supp. I955); Fla. Stat. $\$ 734.31$ (I953); Iowa Code $\$ 633.50$ (I954).

${ }^{130}$ See, e.g., Fla. Stat. §660.10 (I953); Kan. GeN. STAT. §59-706 (I949). 
elsewhere as to movables. ${ }^{137}$ This is a result of the law governing succession of movables under Anglo-American law. ${ }^{138}$ This will not, however, under the law governing validity, determine validity as to immovables, ${ }^{130}$ although it may have that effect under an act such as the Foreign Wills Act, in that the content of the law of the domicile as to this will is established. ${ }^{140}$ There is also the possibility that the situs court of immovables will bar further contest on similar issues under similar law by the doctrines of res judicata. ${ }^{\mathbf{1 4 1}}$ Because of an in rem concept of probate and administration jurisdiction, the doctrines of full faith and credit are probably not yet applicable to findings of validity of the will. ${ }^{142}$ Nondomiciliary contests probably have no effect beyond the assets before the court hearing the litigation, although it is possible that the more personal aspects of res judicata, such as collateral estoppel, might apply. ${ }^{143}$

Another advantage of prompt probate of the will at the domicile involves the effect of a will construction by the courts in the domicile. The conflicts rules here are an interesting, though somewhat confusing, combination of choice of law and res judicata. In cases involving movables, the construction by the domicile is given effect as the most pertinent expression of what the governing law has to say about the case at hand. In addition, alternative references in construction may be foreclosed by concepts of res judicata. ${ }^{\mathbf{1 4 4}}$ While the effect of a domiciliary construction upon a question of immovables at the court of the situs is not controlling as often as in the case of movables, it still is significant. The situs court may adopt the domiciliary construction by reason of its choice of law relating to construction of documents, ${ }^{145}$ or by reason of a foreign execution statute, ${ }^{146}$ or by reason of doctrines

${ }^{137}$ See Lee v. Monks, 318 Mass. 513, 62 N.E.2d 657 (1945); Martin v. Stovall, I03 Tenn. I, 52 S.W. 296 (1899); In re Orrantia's Estate, 36 Ariz. 311, 285 Pac. 266 (1930); Rackemann v. Taylor, 204 Mass. 394, 90 N.E. 552 (I910).

${ }^{138}$ See Restatement, Conflict of Laws $\$ 470$ (I) (1934); Goodrich, op. cit. stipra note 1. at 525; cf. Evansville Ice and Cold Storage Co. v. Winsor, 148 Ind. 682, 48 N.E. 592 (1897); Ives v. Salisbury's Heirs, 56 Vt. 565 (1884).

${ }^{130}$ Clarke v. Clarke, I78 U. S. I 86 (I900); In re Barrie's Estate, 240 lowa 431 , 35 N.W.2d 658 (1949); Hofferd v. Coyle, 212 Ind. 520, 8 N.E.2d 827 (1937).

${ }_{140}$ See Crippen v. Dexter, 79 Mass. 330 ( 1859 ). See note 14 sttpra for citations of statutes recognizing wills valid under the law of the place of execution or some personal law of the testator.

${ }^{141}$ See In re Hunter's Estate, I90 Okla. 284,122 P.2d roi7 (1942); Loewenthal v. Mandell, I25 Fla. 685, x70 So. 169 (1936); Quinton v. Kendall, 122 Kan. 8x4, 253 Pac. 600 (1927); Hopper v. Nicholas, 106 Ohio St. 292, I 40 N.E. I86 (1922); Willett's Appeal, 50 Conn. 330 (1882). See also Roach v. Jurchak, 182 Md. 646, 35 Atl. I817 (1944); Bryon v. Nash, 110 Va. 329, 66 S.E. 69 (1909). See also Hopkins, The Extra-territorial Effect of Probate Decrees, 53 YALE L. J. 22 I (1944). A different result may be reached in suits not concerning validity of a will or disposition. See Ingersoll v. Coram, 2 II U. S. 335 (1908).

${ }^{142}$ See Riley v. New York Trust Co., 315 U.S. 343 (1942); Baker v. Baker, Eccles Co., 2.42 U.S. 394 (1917); Clarke v. Clarke, 178 U.S. 186 (1900); cf. Ingersoll v. Coram, supra note I41.

${ }^{143}$ See Treinies v. Sunshine Mining Co., 308 U.S. 66 (1939); cf. Riley v. New York Trust Co., supra note 142.

${ }^{114}$ See Treinies v. Sunshine Mining Co., stupra note 143 .

${ }^{245}$ See, e.g., note rox stupra. See also Simmons v. O'Connor, 149 S.W.2d 1107 ('Tex. Civ. App. 1941).

${ }_{110}$ See Crippen v. Dexter, 79 Mass. 330 (1859). 
of res judicata and the concept of unitary succession. ${ }^{147}$ From these cases, it appears that the domiciliary construction may well have the effect of reducing litigation elsewhere and providing a basis for uniform handling of the estate.

\section{Creditors' Claims and Their Payment}

One of the primary purposes of administration is to pay the debts of the deceased so that assets of the estate may be distributed free of any incumbrance. This purpose is reflected in the policy of affording creditors a reasonable opportunity to present their claims and, if the claim is valid, to receive payment. The usual procedure is to require a creditor to file his claim in writing with the personal representative or the probate court. The claim is then verified and paid or denied by the personal representative. If denied, the creditor brings suit to establish the claim. Claims must be filed within a specified period of time under the statutes of the different states before they can be considered for payment. This period of time limitations is called the nonclaim period and usually is not subject to extension or waiver by the representative or the court. ${ }^{148}$

Anglo-American law generally permits both local and foreign creditors to file in administration at either the domicile or elsewhere. ${ }^{149}$ Under the in rem concept of jurisdiction, a claim may well be filed in more than one jurisdiction. While payment by one representative discharges the debt, rejection or allowance of a claim as to validity in one jurisdiction usually has not been given effect in other jurisdictions. ${ }^{150}$ The conflict-of-laws doctrine in this area is not fully developed and, as yet, tends to be provincial. The claim procedure is usually characterized as procedural, and only the local law of the forum is applied. While actual litigation between one administrator and a creditor may not bar relitigation of the same claim with another administrator, however, ${ }^{151}$ there is some evidence that courts may refuse to permit a domiciliary creditor to file a claim after the nonclaim period has expired at the domicile. ${ }^{152}$ But the courts have substantially recognized the unity of the estate only when the estate is insolvent. In the case of insolvency, creditors in all states

${ }^{147}$ See Keith v. Eaton, 58 Kan. 732, 51 Pac. 271 (1897). See also WoLFF, op. cit. stupra note I, at $59 \mathrm{r}$, and note 106 supra.

${ }^{148}$ See Thomas E. AtKinson, Wills 687 et seq. (2d ed. I953).

${ }^{140}$ E.g., In re Hirsch's Estate, 146 Ohio St. 393, 66 N.E.2d 636 (1946); Coffey v. Durand, 27 Tcnn. App. 704, I67 S.W.2d 684 (1940); Toner v. Conqueror Trust Co., 131 Kan. 651, 293 Pac. 745 (1930); Buckingham Hotel Co. v. Kimberley, 138 Miss. 445, 103 So. 213 (1925); McKee v. Dodd, 152 Cal. 637, 93 Pac. 854 (1908); Tyler v. Thompson, 44 Tex. 497 (1875). In re Kloebe, 28 Ch. D. 175 (1884).

160 Ingersoll v. Coram, 2 I U U.S. 335 (Ig08); Nash v. Benari, II7 Me. 491, I05 Atl. I07 (Ig18); Johnson v. Mckinnon, I29 Ala. 223, 29 So. 696 (Igor); State v. Fulton, 49 S.W. 297 (Tenn. Ch. App. 1898). Contra, Lomas v. Hilliard, 6o N.H. 148 (I880); Goodall v. Marshall, I4 N.H. I6I (1843).

${ }^{201}$ See note 150 stipra.

${ }^{152}$ See Note, Possibilities of a Claimant Barred by Nonclaim Stattute of Domiciliary Jurisdiction Recovering Against an Ancillary Adminstrator, 4I IowA. L. REv. 27I, 273 (1956). 
are permitted to receive a prorated share of the assets located in all states. ${ }^{153}$ Likewise, it seems clear that nonresident creditors must be given priority equal to that of residents in insolvent estates. ${ }^{154}$ This latter limitation may rest on rights under the United States Constitution and, therefore, not apply to certain international estates. It has been stated, for example, that the ancillary administrator may distribute locally if the assets would be subjected to claims by the domicile not recognized at the forum. ${ }^{155}$

The possibility of preventative action in this area of conflicts depends to a great extent upon the persuasive ability of the personal representative. If ancillary administration is to be avoided, it is often necessary to persuade creditors to refrain from requiring local administration and to look to a foreign administration for payment. This and related tasks are made more difficult by the fact that the personal representative usually must wait until the nonclaim period at the domicile has expired before he can safely pay any creditor. ${ }^{156}$ If, however, ancillary administration can be avoided, the possibility of conflicting or harassing litigation with creditors can be reduced by reducing the possible fora. If any possibility of insolvency exists, the personal representative should postpone distribution until the nonclaim period in all administrations has expired before distributing the prorated dividend to the creditors.

A problem sometimes confused with claims against an estate is the matter of a claim against the personal representative. Causes of action by or against a personal representative for acts or transactions occurring since his appointment are personal to him and unaffected by problems of privity between administrations or limitations upon suits by foreign fiduciaries. ${ }^{\mathbf{1 5 7}}$ In these cases, the personal representative can sue or be sued as an individual subject to his duty to account.

\section{E. Nonbarrable Interests and Exempt Assets}

Often related to the problem of what assets are available for payment of creditor's claims are matters relating to the statutory or common-law provisions for benefit of the family or particular members thereof. Some of the problems incident to dower and forced shares have been discussed above, but one or two remain for consideration here. ${ }^{158}$ Many states provide that certain assets of the decedent and certain family

${ }^{153}$ See, e.g., In re Hirsch's Estate, I46 Ohio St. 393, 66 N.E.2d 636 (1946); Estate of Hanreddy, 176 Wis. 570, I86 N.W. 744 (1922); Ramsay v. Ramsay, I96 Ill. 179, 63 N.E. 618 (1902); Goodall v. Marshall, II N.H. 88 (I840).

15t See Blake v. McClung, x72 U.S. 239 (1898).

${ }^{150}$ See In re Lorillard, [1922] 2 Ch. 638 (C.A.); Lawrence v. Kitteridge, 21 Conn. 577 (1852). See also WoLFF, op. cit. supra note 1 , at 604 .

${ }^{150}$ Cf. Colo. Rev. Stat. $\$$ I52-6-3 (I953), requiring administration within a year to charge local property with debts. See also NEB. Rev. StAT. $\$ 30-224$ (1943).

${ }_{157}$ See Turner v. Alton Banking and Trust Co., 166 F.2d 305 (8th Cir. 1948); Harc v. O'Bricn, 233 Pa. 330, 82 Atl. 475 (I912); Moore v. Kraft, I79 Fed. 685 (7th Cir. I9r2); Gleason v. Northwestern Mut. Life Ins. Co., 189 N.Y. I00, 8I N.E. 777 (I907); Traflet v. Empire Life Ins. Co., 64 N.J.L. 387, 46 Atl. 204 (1900).

${ }^{168}$ See discussion at note 35 supra. 
interests shall be free of the claims of creditors. ${ }^{159}$ Priorities and exemptions are generally regarded as matters to be determined by the forum's local law. ${ }^{160}$ Because homestead exemptions require the acquisition of a local home by the deceased before becoming effective, this particular family interest usually is of concern only in the domiciliary administration. ${ }^{\mathbf{1 6 1}}$

The family allowance cases indicate quite varied approaches to choice of law, with some states permitting allowances in ancillary administration, although most indicate that the matter is one to be considered at the domicile. ${ }^{162}$ Clearly, the domicile has the primary interest, and the personal representative should advise the widow to make her claim there. If it is necessary, because of the location of assets, to obtain a family allowance away from the domicile, the personal representative may well be advised to restrict the amount to that allowed at the domicile, if it be the lesser amount. ${ }^{163}$ This is a matter which could well be called to the testator's attention so that insurance or some other device can be set up to carry the family over the period of administration until distribution of the beneficiaries' shares.

\section{F. Apportionment of Federal Estate Taxes}

One of the more difficult problems of administration of large estates in the United States is caused by the imposition of federal taxes and their proration by state statutes among various beneficiaries. The common-law solution to the distribution of the burden of estate taxes was to pay them from the residue of the probate estate. This rule has been changed by decision or statute in half of the states to provide that such taxes shall be apportioned among the recipients of the assets making up the estate for tax purposes. ${ }^{164}$ As far as testamentary gifts are concerned, there have been few decided cases. It may perhaps be expected that many courts will, when faced with the problem, apply the law of the decedent's domicile to determine apportionment as to movables, and the law of the situs as to im-

${ }^{150}$ E.g., as to dower or forced share, see Fr.A. STAT. $\$ 73$ T.34 (I953); IND. ANN. Stat. $\$ 6-202$ (Burns I953); Thompson v. Union and Mercantile Trust Co., I64 Ark. 4II, 262 S.W. 324 (I924); I AMrerican LAw of Properti $\$ 5.42$ (I952); as to family allowances, see Arr. Stat. AnN. $\$ 62-250 \mathrm{I}$ (Supp. I953); Colo. Rev. Stat. \$152-I2-I6 (I953); Idaho Code Ann. \$ 15-504 (1947); Kan. Gen. STAT. $\$ 59-403$ (I949); as to personal and household effects, sec Ala. Code tit. 7, $\$ 664$ (I940); IowA Code $\$ 635.7$ (I954); Kan. Gen. Stat. $\$ 59-403$ (I949); Minn. Stat. $\$ 525.15$ (I953); as to homestead, see Ala. Code tit. 7, $\$ 66 \mathrm{I}$ (Supp. I953); Cal. Prob. Code $\$ 660$ (1949); Fla. Const. art. $\mathrm{X}, \S \mathrm{I} ; \mathrm{MinN}$. Stat. $\$ 525.39$ (1953).

${ }^{200}$ See, e.g., Jaeglin v. Moakley, 236 Mo. App. 254, I5x S.W.2d 524 (I94I); Sanders v. Armour Fertilizer Works, 292 U.S. Igo (1934); cf. Henderson v. Usher, 125 Fla. 709, 170 So. 846 (1936).

${ }^{101}$ See In re Graham's Estate, 73 Ariz. 179, 239 P.2d 365 (I95I); Matthews v. Matthews, 249 Ala. 6II, 32 So.2d 5I4 (I947); S. D. Scott \& Co. v. Jones, 230 N.C. 74, 52 S.E.2d 219 (1949); Collins v. Collins, 150 Fla. 374, 7 So.2d 443 (1942); Leonetti v. Tolton, 264 Mich. 618, 250 N.W. 512 (1933).

${ }^{102}$ See Scoles, supra note 64 , at 172.

${ }^{103}$ See $i d$. at $\mathbf{r} 80$.

${ }^{104}$ See, e.g, Henderson v. Usher, I25 Fla. 709, I70 So. 846 (r936); Regents of the University System v. Trust Co., 194 Ga. 255, 2 S.E.2d 69I (I942); Louisville Trust Co. v. Walter, 306 Ky. 756, 207 S.W.2d 328 (1948); Ark. Stat. ANn. $\$ 63-150$ (1947): Cal. Prob. Code $\$ 970-77$ (1949); Conn. Gen. Stat. $\$ \$ 2075-8$ I (1949); N. J. Stat. ANn. $\$ 3$ A: 25-30-38 (r95I); N. Y. Dec. Est. LAw § r24; PA. Stat. ANN. tit. 20, $\$ 88 \mathrm{I}-87$ (Supp. I955). See generally Scoles, Apportionment of Federal Estate Taxes and Conflict of Laws, 55 CoLum. L. Rev. 261 (1955). 
movables. ${ }^{165}$ Nearly all the litigation has been in New York, whose courts consistently have applied the law of the decedent's domicile in all cases to determine apportionment. ${ }^{166}$ Inter vivos transfers may also be required to bear a share of the tax. Of the three jurisdictions that have considered the conflicts problem of apportionment against inter vivos trusts, Minnesota and Massachusetts have applied the law of the place of the creation and administration of the trust, and New York has applied the law of the decedent's domicile at death. ${ }^{107}$

Because he must pay the tax and enforce contribution if apportionment is required, the domiciliary personal representative is most concerned with this problem. He may use his full power of retention and set off to enforce contribution, and he may sue to enforce contribution. ${ }^{168}$ Here, again, sympathetic personal representatives of the different administrations are needed to negotiate effective apportionment.

Fortunately, this is a matter subject both to the decedent's intention and to control by the draftsman. Every dispositive instrument should have an express provision stating the wishes of the testator with regard to apportionment of estate taxes. If the taxes are to be paid from the residue, this should be stated. If the testator desires to apportion the tax, this should be stated by indicating which gifts are to contribute and which, if any, are not. Of particular concern are inter vivos dispositions; as to these, the intention of the testator should be indicated in both the will and the inter vivos instrument to assure the result without regard to the conflicts attitude of the courts which might later pass on the question. ${ }^{100}$

\section{G. Distribution}

Many of the local-law peculiarities that distort the testamentary scheme may be remedied or at least alleviated by judicious handling of distribution. Distribution of immovables is made at the situs, while distribution of movables is usually made at the principal place of administration, which, under Anglo-American law, is the domicile at death. ${ }^{\mathbf{1 7 0}}$ Distribution of movables may be made in ancillary admin-

${ }^{106}$ Cf. Riggs v. Del Drago, 3I7 U.S. 95 (1942).

${ }^{106}$ In re Peabody's Estate, I15 N.Y.S.2d 337 (Sup. Ct. 1952); In re Ruperti's Estate, 194 Misc. 376, 86 N.Y.S.2d 887 (Surr. Ct. 1949); In re Bernie's Estate, 74 N.Y.S.2d 887 (Surr. Ct. I947); Goodman's Estate, 76 N.Y.S.2d 706 (Surr. Ct. I946); In re Dommerich's Estate, 74 N.Y.S.2d 283 (Surr. Ct. 1945).

${ }_{107}$ First Nat'l Bank v. First Trust Co., 242 Minn. 226, 64 N.W.2d 524 (1954); Isaacson v. Boston Safe Deposit \& Trust Co., 325 Mass. 469, 91 N.E.2d 334 (1950); In re Gato's Estate, 276 App. Div. 651, 97 N.Y.S.2d I7I (rst Dep't 1950). See also Knowles v. National Bank of Detroit, 76 N.W.2d 813 (Mich. 1956).

${ }^{108}$ See In re Peabody's Estate, 115 N.Y.S.2d 337 (Sup. Ct. 1952); In re Gato's Estate, supra note 167; Central Hanover Bank v. Peabody, 190 Misc. 66, 68 N.Y.S.2d 256 (Sup. Ct. 1947); cf. Matter of Buckman, 270 App. Div. 707, 62 N.Y.S.2d 337 (Ist Dep't, 1946). See also note 164 stpra.

${ }_{100}$ The attitude of Massachusetts, Isaacson v. Boston Safe Deposit and Trust Co., 325 Mass. 469, 91 N.E.2d 334 (1950), and Minnesota, First Nat'l Bank v. First Trust Co., 242 Minn. 226, 64 N.W.2d 524 (1954), is that apportionment against the inter vivos trust is governed by the law applicable to the trust and that the domicile of the settlor at death is without jurisdiction to impose the obligation. Consequently, provision in both instruments would seem to overcome the possible invalidating effects of this approach.

${ }^{170}$ See Goodrich, op. cit. supra note I, at 576; KY. Rev. Stat. $\$ 395.260$ (1953); ME. Rev. Stat. c. $156, \S 32$ (1954). 
istration if some policy of the forum would be offended by the proposed distribution of the principal administration. ${ }^{171}$ Examples are undue taxes, limitation on charitable gifts, ${ }^{172}$ or even payment to creditors or claimants whose claims are not recognized in the other jurisdiction. ${ }^{173}$ If there are substantial assets at the domicile or any other chosen forum which will accede to the testator's wishes, this forum can retaliate against foreign distribution by adjusting its own distribution to offset that of another administration. In cases of elections against the will in one jurisdiction and taking under it in another, this method of retaliation is often used to restore, as far as available assets permit, what the forum believes to be the preferred testamentary scheme. While perhaps sometimes used to enforce provincial attitudes by an ancillary forum, this is a useful device for the domicile, as the jurisdiction most intimately interested in the decedent, his estate, and family, to give effect to the testator's plans in light of the domicile's prevailing policy. ${ }^{174}$ This suggests that wherever possible, the principal administration should be the last to distribute and that the principal personal representative guide himself by the domiciliary law in determining questions of elections and adjustment of foreign distribution. The distribution control is, of course, more effective if there are substantial amounts available for distribution at the domicile.

Distribution to foreign fiduciaries under terms of testamentary trusts or life estates or gifts to minors may also well raise important conflicts problems. In all such cases, the distributing fiduciary must require qualification under the various laws having contact. Extreme caution must be exercised in assuming that the concept of the fiduciaries' duties and beneficiaries' rights, as understood in Anglo-American law, can efficiently be transferred to the system of another country. Both the effect of the gift and the transfer to a foreign fiduciary, as well as the latter's qualifications, must be thoroughly explored by the draftsman and the advisor of the distributing fiduciary. ${ }^{175}$ Quite often, a trust arrangement, with administration in a familiar forum, with appropriate precaution by way of bond, is better than subjecting the assets to the uncertainty of an unfamiliar foreign concept. ${ }^{176}$

\section{V}

\section{Conceusron}

As in most areas of preventive law, the best way to avoid conflict-of-laws problems in succession is to have the estate owner's assets and estate plans so arranged

${ }^{171}$ See Lawrence v. Kitteridge, 2I Conn. 577 (1852).

${ }_{172}$ See Matter of Beresford's Estate, ${ }_{4} 6$ Misc. I40, 262 N.Y. Supp. 78 (Surr. Ct. I932); Graveley v. Graveley, 25 S.C. I (1885); Matter of Hughes, 95 N.Y. 55 (I884); cf. In re Lawrence's Will, 93 Vt. 424 , 108 Atl. 387 (1919).

${ }_{173}^{17 n}$ re Lorillard, [1922] 2 Ch. 638 (C.A.); cf. Caruso v. Caruso, 106 N.J. Eq. 130, I48 Atl. 882 (Ct. Err. \& App. I930).

${ }^{17}$ See Griley v. Griley, 43 So.2d 350 (Fla. r949); Murphy v. Murphy, 125 Fla. 855, 170 So. 856 (1936); In re Lawrence's Estate, 93 Vt. 424, ro8 Atl. 387 (r9r9); Cummings' Estate, 153 Pa. 397, 25 Atl. 1125 (1893); Van Dyke's Appeal, 60 Pa. 481 (1869). See also Scoles, Conflict of Laws and Elections in Administration of Decedents' Estates, 30 IND. L. J. 293, 308 (I955).

${ }^{175} \mathrm{Sec}$ WorfF, op. cit. stipra note $\mathrm{x}$, at $59 \mathrm{r}$.

${ }^{179}$ See discussion at notes 77 and 87 stepra. 
that they do not arise. This is, of course, much easier to say than to do, as few clients are willing to so limit their affairs as to conform to what an attorney might suggest in order to assure a most favorable post-mortem factual situation. Nevertheless, so far as the interests of the client permit, the simplest solution to any potential conflict-of-laws problem is to prevent any "conflict" from occurring. Consequently, an effective approach in this area is first to locate assets in states with internal law or conflict-of-laws rules sympathetic to the control desired by the testator; second, to satisfy the internal law requirements of jurisdictions having the controlling contacts with the estate; third, to use express clauses indicating the intention of the estate owner in matters subject to his intent; fourth, to include express choiceof-law clauses in the estate instruments; and finally, and perhaps most important, to impress upon the client the necessity of periodic review of his entire dispositive scheme in order to assure the accommodation of changed circumstances that would otherwise distort his planned distribution. 